\title{
molecules
}

ISSN 1420-3049

www.mdpi.com/journal/molecules

Article

\section{Antibacterial and Herbicidal Activity of Ring-Substituted 3-Hydroxynaphthalene-2-carboxanilides ${ }^{\dagger}$}

Jiri Kos ${ }^{1}$, Iveta Zadrazilova ${ }^{1,2,3}$, Matus Pesko ${ }^{4}$, Stanislava Keltosova ${ }^{5}$, Jan Tengler ${ }^{1}$, Tomas Gonec ${ }^{1}$, Pavel Bobal ${ }^{1}$, Tereza Kauerova ${ }^{5}$, Michal Oravec ${ }^{6}$, Peter Kollar ${ }^{5}$, Alois Cizek ${ }^{2,3}$, Katarina Kralova ${ }^{4}$ and Josef Jampilek ${ }^{1, *}$

1 Department of Chemical Drugs, Faculty of Pharmacy, University of Veterinary and Pharmaceutical Sciences, Palackeho 1/3, 61242 Brno, Czech Republic

2 Department of Infectious Diseases and Microbiology, Faculty of Veterinary Medicine, University of Veterinary and Pharmaceutical Sciences, Palackeho 1/3, 61242 Brno, Czech Republic

3 CEITEC VFU, University of Veterinary and Pharmaceutical Sciences, Palackeho 1/3, 61242 Brno, Czech Republic

4 Institute of Chemistry, Faculty of Natural Sciences, Comenius University, Mlynska dolina Ch-2, 84215 Bratislava, Slovakia

5 Department of Human Pharmacology and Toxicology, Faculty of Pharmacy, University of Veterinary and Pharmaceutical Sciences, Palackeho 1/3, 61242 Brno, Czech Republic

6 Global Change Research Centre AS CR, Belidla 986/4a, 60300 Brno, Czech Republic

$\dagger$ Preliminary results were presented at The Sixteenth Electronic Conference on Synthetic Organic Chemistry (ECSOC-16, http://www.sciforum.net/presentation/1009), 1-30 November 2012 (paper B1009).

* Author to whom correspondence should be addressed; E-Mail: josef.jampilek@gmail.com; Tel.: +420-54-156-2926.

Received: 23 May 2013; in revised form: 17 June 2013 / Accepted: 4 July 2013 /

Published: 8 July 2013

Abstract: In this study, a series of twenty-two ring-substituted 3-hydroxy- $N$ phenylnaphthalene-2-carboxanilides were prepared and characterized. The compounds were tested for their activity related to inhibition of photosynthetic electron transport (PET) in spinach (Spinacia oleracea L.) chloroplasts. Primary in vitro screening of the synthesized compounds was also performed against four Staphylococcus strains and against two mycobacterial species. 3-Hydroxy- $N$-(2-methoxyphenyl)naphthalene-2-carboxamide showed 
high biological activity $(\mathrm{MIC}=55.0 \mu \mathrm{mol} / \mathrm{L})$ against $S$. aureus as well as methicillinresistant strains. $N$-(2-Fluorophenyl)-3-hydroxynaphthalene-2-carboxamide showed higher activity $(\mathrm{MIC}=28.4 \mu \mathrm{mol} / \mathrm{L})$ against $M$. marinum than the standard isoniazid and 3-hydroxy- $N$-(4-nitrophenyl)naphthalene-2-carboxamide expressed higher activity $(\mathrm{MIC}=13.0 \mu \mathrm{mol} / \mathrm{L})$ against $M$. kansasii than the standard isoniazid. Cytotoxicity assay of effective antimicrobial compounds was performed using the human monocytic leukemia THP-1 cell line. The PET-inhibiting activity expressed by $\mathrm{IC}_{50}$ value of the most active compound 3-hydroxy- $N$-(3-nitrophenyl)naphthalene-2-carboxamide was $16.9 \mu \mathrm{mol} / \mathrm{L}$. The structure-activity relationships of all compounds are discussed.

Keywords: hydroxynaphthalene-2-carboxanilides; lipophilicity; photosynthetic electron transport inhibition; spinach chloroplasts; in vitro antibacterial activity; in vitro antimycobacterial activity; in vitro cytotoxicity; structure-activity relationships

\section{Introduction}

The increasing number of bacterial, mycobacterial and associated fungal infections underlines the importance of searching for new antimicrobial chemotherapeutics [1]. Tuberculosis and other mycobacterial diseases are common, and in many cases lethal, infectious illnesses caused by various strains of pathogenic mycobacteria. The genus Mycobacterium consists of a closely related group of fast and slow-growing species. Mycobacterium tuberculosis causes one of the most serious human infections, tuberculosis. Difficulties should be considered while studying M. tuberculosis, especially a slow growth rate and the requirement to work in high containment biosafety facilities. To lower risks and make manipulation in the laboratory easier, surrogate model pathogens for M. tuberculosis can be used in laboratory studies. M. marinum is very closely related to the M. tuberculosis; it is the cause of TB-like infections in poikilothermic organisms, especially frogs and fish. M. marinum is a good model for studying because of the lower risk for laboratory workers, genetic relatedness and similar pathology to human TB [2,3]. However, because of $M$. tuberculosis, the pathogenic role of nontuberculous mycobacteria (NTM) in humans was overshadowed for a long time. M. kansasii, the most virulent of the NTM, causes nontuberculous mycobacterial lung infections which are very common nowadays and can be indistinguishable from tuberculosis [4]. That is the reason why $M$. marinum and $M$. kansasii are often chosen as model species for screening of prospective antimycobacterial drugs to control mycobacterial diseases.

The treatment of tuberculosis and nontuberculous diseases is mediated by administration of various antimicrobial chemotherapeutics, however massive using of these drugs is considered to be the main reason for increased antibiotic resistance among bacteria [5,6]. The antibiotic resistance of important Gram-positive pathogen, Staphylococcus aureus, has become one of the most challenging and persistent worldwide health problems. Methicillin-resistant $S$. aureus (MRSA) was first described in 1961 and since then has become one of the most common clinically relevant bacterial pathogens isolated almost all over the World. Even though originally limited to hospitals, nowadays MRSA is an increasing cause of infections in the community. Recent studies have shown that, despite antibacterial 
therapy, MRSA infections are still associated with serious clinical consequences (treatment failure, higher morbidity and mortality, prolonged hospitalization, etc.). Because of the changing features of MRSA, it is one of the most difficult bacteria for clinicians to treat. The emergence of resistance to currently available drugs, their toxicity and general lack of oral agents justify an urgent need for new anti-MRSA agents [7,8].

Both pharmaceuticals and pesticides are designed to target particular biological functions, and in some cases these functions overlap in their molecular target sites, or they target similar processes or molecules. Taking into consideration that herbicides may also have molecular sites of action in mammals, until recently most pharmaceutical companies had pesticide divisions, sometimes with a different name. All compounds generated by either division of the company were evaluated for both pesticide and pharmaceutical uses. In the past, some leading pesticides have become pharmaceuticals and vice versa [9-11]. Moreover, good correlation between microbiological activities and herbicidal effects was found [12-15].

The presence of an amide (-NHCO-) group [16-20] is characteristic of a number of herbicides acting as photosynthesis inhibitors. Over $50 \%$ of commercially available herbicides act by reversibly binding to photosystem II (PS II), a membrane-protein complex in the thylakoid membranes, which catalyses the oxidation of water and the reduction of plastoquinone [21], and thereby inhibit photosynthesis [22-24].

Promising results of biological screening of some salicylanilides (their antimicrobial, antimycobacterial, antifungal, molluscicidal and herbicidal action) [17-19,25-33] inspired us to prepare and evaluate ring-substituted 3-hydroxynaphthalene-2-carboxanilides. The design of these 3hydroxy- $N$-phenylnaphthalene-2-carboxanilides is based on ring analogy with salicylanilides (2hydroxy- $N$-phenylbenzamide). Thus in the context of the previously-published results [16-20,25-33], primary in vitro screening of the synthesized compounds was also performed against four Staphylococcus strains, three of which were methicillin-resistant Staphylococcus aureus strains, and against two mycobacterial species, such as Mycobacterium marinum and M. kansasii.

\section{Results and Discussion}

\subsection{Chemistry}

All the studied compounds were prepared according to Scheme 1. Modified microwave-assisted synthesis [29] facilitated the process of obtaining 3-hydroxynaphthalene-2-carboxanilides, thus synthesis of the target compounds was carried out only by one step. At first the carboxyl group was activated with phosphorus trichloride. The final amide was immediately formed by aminolysis of the acyl chloride by ring-substituted aniline in dry chlorobenzene. All the compounds were recrystallized from ethanol; their HPLC purity exceeded 97\%. By microwave-assisted synthesis reaction times were shortened from hours [34-37] to minutes, and yields of most compounds (except 2- $\mathrm{NO}_{2}$ derivative 8a) were more than $65 \%$, for details see Section 3.2 . 
Scheme 1. Synthesis of ring-substituted 3-hydroxynaphthalene-2-carboxanilides 1-8c.

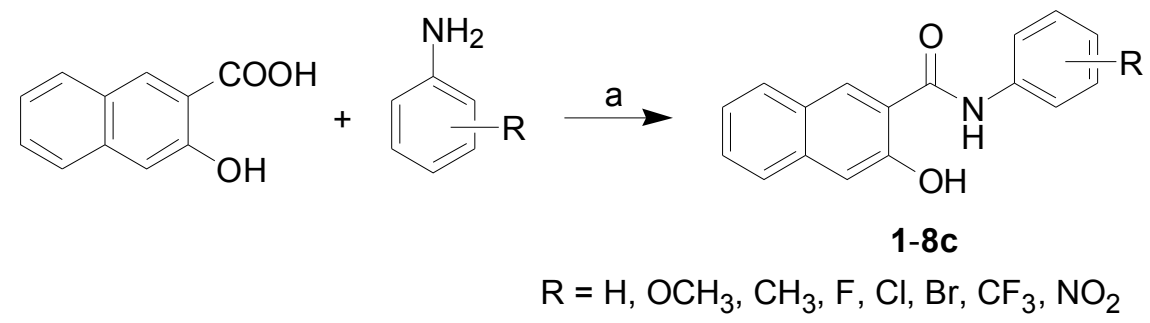

Reagents and conditions: (a) $\mathrm{PCl}_{3}$, chlorobenzene, $\mathrm{MW}$.

\subsection{Lipophilicities}

Lipophilicity is a property that has a major effect on solubility, absorption, distribution and biotransformation as well as pharmacological activity, because drugs cross biological membranes through passive transport, which strongly depends on their lipophilicity. Lipophilicity has been studied and applied as an important drug property for decades. Lipophilicity of the studied compounds was determined by RP-HPLC as capacity factor logarithm $(\log k)$ and calculated as $\log P$ using $\mathrm{ACD} /$ Percepta software. The results of ring-substituted 3-hydroxynaphthalene-2-carboxanilides 1-8c are shown in Table 1 and illustrated in Figure 1. The highest experimental lipophilicity was found for 3-hydroxy- $N$-(4-trifluoromethylphenyl)naphthalene-2-carboxamide (7c), while 3-hydroxy$N$-phenylnaphthalene-2-carboxamide (1) showed the lowest $\log k$ value. It is important to note that lipophilicity also has a great impact on target and off-target interactions, as mentioned below.

The results obtained with the discussed compounds show that the experimentally-determined lipophilicities $(\log k)$ of the meta- and para-substituted compounds are in accordance with the calculated $\log P$ values as shown in Figure 1B, while ortho-substituted derivatives showed poor match, see Figure 1A. The most significant deviations within the dependence illustrated in Figure 1B can be observed for $4-\mathrm{CF}_{3}(\mathbf{7 c})$ and $4-\mathrm{NO}_{2}(\mathbf{8 c})$. The influence of $\mathrm{R}$ substituents on lipophilicity is as follows: $\mathrm{H}<\mathrm{OCH}_{3}<\mathrm{CH}_{3}<\mathrm{F}<\mathrm{NO}_{2}<\mathrm{Cl}<\mathrm{Br} \leq \mathrm{CF}_{3}$. Within the individual series the lipophilicity determined by $\log k$ values increases for halogens and methyl substituents as follows: ortho $<$ para $<$ meta; for methoxy substituent as follows: para $<$ ortho $<$ meta, and for $\mathrm{CF}_{3}$ and $\mathrm{NO}_{2}$ as follows: ortho $<$ meta $<$ para. Generally, it could be concluded that the prediction power of the used experimental $\log k$ or calculated $\log P$ values, especially for meta- and para-substituted derivatives, may be a good tool for searching potential drugs. It can be assumed that $\log k$ values specify lipophilicity within individual series of the studied compounds.

\subsection{Inhibition of Photosynthetic Electron Transport (PET) in Spinach Chloroplasts}

The activity of the evaluated naphthanilide derivatives related to inhibition of photosynthetic electron transport (PET) in spinach (Spinacia oleracea L.) chloroplasts was moderate or low relative to the standard, see Table 1. Generally compounds showed poor aqueous solubility. Only seven compounds from twenty-two tested compounds could be evaluated. PET inhibition by $\mathbf{1}, \mathbf{2 c}-\mathbf{5 c}, \mathbf{6 b}, \mathbf{6 c}$ and $\mathbf{7 b}, \mathbf{7} \mathbf{c}$ could not be determined due to precipitation of the compounds during the experiments. With respect to these small but specifically substituted groups of compounds some structure-activity relationships (SAR) can be proposed. Compound $\mathbf{8 b}\left(\mathrm{R}=3-\mathrm{NO}_{2}\right)$ expressed the highest PET-inhibiting 
activity

$\left(\mathrm{IC}_{50}=16.9 \mu \mathrm{mol} / \mathrm{L}\right)$, while compound $8 \mathrm{c}\left(\mathrm{R}=4-\mathrm{NO}_{2}\right)$ expressed the lowest PET-inhibiting activity $\left(\mathrm{IC}_{50}=187.5 \mu \mathrm{mol} / \mathrm{L}\right)$.

Table 1. Structure of ring-substituted 3-hydroxynaphthalene-2-carboxanilides 1-8c, experimentally determined values of lipophilicity $\log k$, calculated values of $\log P$ and electronic Hammett's $\sigma$ parameters, $\mathrm{IC}_{50}[\mu \mathrm{mol} / \mathrm{L}]$ values related to PET inhibition in spinach chloroplasts in comparison with 3-(3,4-dichlorophenyl)-1,1-dimethylurea (DCMU) standard, in vitro anti-Staphylococcus activities [MIC $(\mu \mathrm{mol} / \mathrm{L})]$ in comparison with standards ampicillin (APC), in vitro antimycobacterial activity [MIC ( $\mu \mathrm{mol} / \mathrm{L})]$ of compounds 1-8c compared to isoniazid (INH) standard and in vitro cytotoxicity assay $\left(\mathrm{LD}_{50}\right)$ of selected compounds.

\begin{tabular}{|c|c|c|c|c|c|c|c|c|c|c|c|c|}
\hline \multirow{3}{*}{ Comp. } & \multirow{3}{*}{$\mathbf{R}$} & \multirow{3}{*}{$\log k$} & \multirow{3}{*}{$\log P^{a}$} & \multirow{3}{*}{$\boldsymbol{\sigma}^{a}$} & \multicolumn{8}{|c|}{$[\mu \mathrm{mol} / \mathrm{L}]$} \\
\hline & & & & & \multirow{2}{*}{$\begin{array}{l}\text { PET } \\
\text { IC }_{50}\end{array}$} & \multicolumn{6}{|c|}{ MIC } & \multirow[t]{2}{*}{$\mathbf{L D}_{\mathbf{5 0}}$} \\
\hline & & & & & & SA & $\begin{array}{c}\text { MRSA } \\
63718 \\
\end{array}$ & $\begin{array}{c}\text { MRSA } \\
630 \\
\end{array}$ & $\begin{array}{c}\text { MRSA } \\
3202 \\
\end{array}$ & MM & MK & \\
\hline 1 & $\mathrm{H}$ & 0.6310 & 4.52 & 0 & $b$ & $>972$ & $>972$ & $>972$ & $>972$ & 122 & 972 & - \\
\hline $2 a$ & $2-\mathrm{OCH}_{3}$ & 0.6916 & 4.61 & -0.28 & 59.5 & 55.0 & 55.0 & 55.0 & 55.0 & 873 & 218 & $>30$ \\
\hline $2 b$ & $3-\mathrm{OCH}_{3}$ & 0.6971 & 4.56 & 0.12 & 53.4 & $>873$ & $>873$ & $>873$ & $>873$ & $>873$ & 54.6 & $>30$ \\
\hline $2 c$ & $4-\mathrm{OCH}_{3}$ & 0.5951 & 4.37 & -0.27 & $b$ & $>873$ & $>873$ & $>873$ & $>873$ & $>873$ & 873 & - \\
\hline $3 a$ & $2-\mathrm{CH}_{3}$ & 0.6936 & 4.85 & -0.17 & $b$ & $>923$ & $>923$ & $>923$ & 462 & 462 & 115 & - \\
\hline $3 \mathbf{b}$ & $3-\mathrm{CH}_{3}$ & 0.8831 & 4.85 & -0.07 & $b$ & $>923$ & $>923$ & $>923$ & 462 & 923 & 57.7 & $>30$ \\
\hline $3 c$ & 4- $\mathrm{CH}_{3}$ & 0.8753 & 4.85 & -0.17 & $b$ & $>923$ & $>923$ & 462 & 231 & $>923$ & 923 & - \\
\hline $4 a$ & $2-\mathrm{F}$ & 0.7303 & 4.56 & 0.06 & $b$ & $>910$ & $>910$ & 455 & 228 & 28.4 & 56.9 & $>30$ \\
\hline $4 b$ & $3-\mathrm{F}$ & 0.8296 & 4.69 & 0.34 & $b$ & $>910$ & $>910$ & 455 & 228 & 114 & 114 & - \\
\hline $4 c$ & $4-\mathrm{F}$ & 0.7317 & 4.70 & 0.06 & $b$ & $>910$ & $>910$ & 455 & 228 & 910 & 114 & - \\
\hline $5 a$ & $2-\mathrm{Cl}$ & 0.9509 & 5.02 & 0.22 & $b$ & $>860$ & $>860$ & $>860$ & 215 & 860 & 860 & - \\
\hline $5 b$ & $3-\mathrm{Cl}$ & 1.0796 & 5.25 & 0.37 & $b$ & $>860$ & $>860$ & 430 & 215 & $>860$ & 860 & - \\
\hline $5 c$ & $4-\mathrm{Cl}$ & 1.0687 & 5.24 & 0.23 & $b$ & $>860$ & $>860$ & $>860$ & $>860$ & $>860$ & 430 & - \\
\hline $6 a$ & $2-\mathrm{Br}$ & 0.9715 & 5.06 & 0.22 & 43.2 & $>748$ & $>748$ & $>748$ & $>748$ & $>748$ & 748 & - \\
\hline $6 b$ & $3-\mathrm{Br}$ & 1.1536 & 5.39 & 0.39 & $b$ & $>748$ & $>748$ & $>748$ & 187 & $>748$ & 748 & - \\
\hline $6 c$ & $4-\mathrm{Br}$ & 1.1459 & 5.28 & 0.23 & $b$ & $>748$ & $>748$ & $>748$ & 187 & $>748$ & 374 & - \\
\hline $7 a$ & $2-\mathrm{CF}_{3}$ & 0.8762 & 5.42 & 0.51 & 105.2 & $>773$ & $>773$ & $>773$ & 97 & 193 & 193 & $28.6 \pm 0.5$ \\
\hline $7 b$ & $3-\mathrm{CF}_{3}$ & 1.2053 & 5.49 & 0.43 & $b$ & $>748$ & $>748$ & 374 & 187 & $>748$ & 748 & - \\
\hline $7 c$ & $4-\mathrm{CF}_{3}$ & 1.2835 & 5.33 & 0.51 & $b$ & $>748$ & $>748$ & 374 & 187 & $>748$ & 187 & - \\
\hline $8 a$ & $2-\mathrm{NO}_{2}$ & 0.8710 & 4.51 & 0.77 & 106.6 & $>830$ & $>830$ & 415 & 415 & 830 & 830 & - \\
\hline $8 b$ & $3-\mathrm{NO}_{2}$ & 0.8143 & 4.64 & 0.71 & 16.9 & $>830$ & $>830$ & $>830$ & $>830$ & $>830$ & 415 & $2.5 \pm 0.9$ \\
\hline $8 c$ & $4-\mathrm{NO}_{2}$ & 0.9175 & 4.65 & 0.78 & 187.5 & $>830$ & $>830$ & $>830$ & $>830$ & $>830$ & 13.0 & $<0.37$ \\
\hline DCMU & - & - & - & & 1.9 & - & - & - & - & - & - & - \\
\hline APC & - & - & - & & & 5.7 & $>45.8$ & $>45.8$ & $>45.8$ & - & - & - \\
\hline INH & & & & & & - & - & - & - & 467 & 29.2 & - \\
\hline
\end{tabular}

${ }^{a}$ calculated using sw. ACD/Percepta ver. $2012 ;{ }^{b}$ precipitation during experiment; $S A=$ Staphylococcus aureus ATCC 29213; MRSA = clinical isolates of methicillin-resistant S. aureus 63718, SA 630 and SA 3202 (National Institute of Public Health, Prague, Czech Republic); MM = Mycobacterium marinum CAMP 5644, MK = M. kansasii DSM 44162. 
Figure 1. Comparison of experimentally found $\log k$ values with calculated $\log P$ of ortho-substituted (A) and meta- and para-substituted derivatives (B).
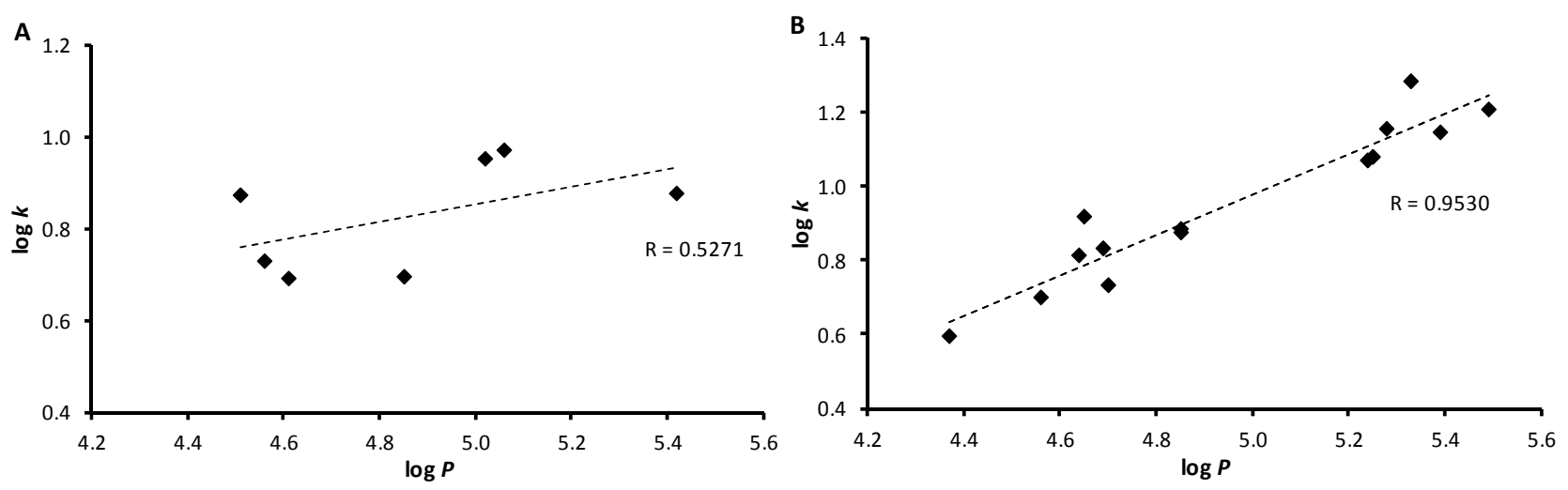

The PET-inhibiting activity was expressed by negative logarithm of $\mathrm{IC}_{50}$ value (compound concentration in mol/L causing 50\% inhibition of PET). Despite the relatively low inhibitory activity of the studied compounds, correlations between $\log \left(1 / \mathrm{IC}_{50}[\mathrm{~mol} / \mathrm{L}]\right)$ and the lipophilicity of compounds expressed as $\log k$ or electronic properties of individual anilide substituents expressed as Hammett's $\sigma$ parameters were performed, see Figure 2. Based on the obtained results it is not possible to decide, whether some of ortho-, meta- or para-positions are preferred from the point of view of PET-inhibiting activity.

Figure 2. Relationships between PET inhibition $\log \left(1 / \mathrm{IC}_{50}\right)[\mathrm{mol} / \mathrm{L}]$ in spinach chloroplasts and lipophilicity expressed as $\log k(\mathbf{A})$ or $N$-substituent electronic Hammett's $\sigma$ parameters (B) of selected studied compounds.
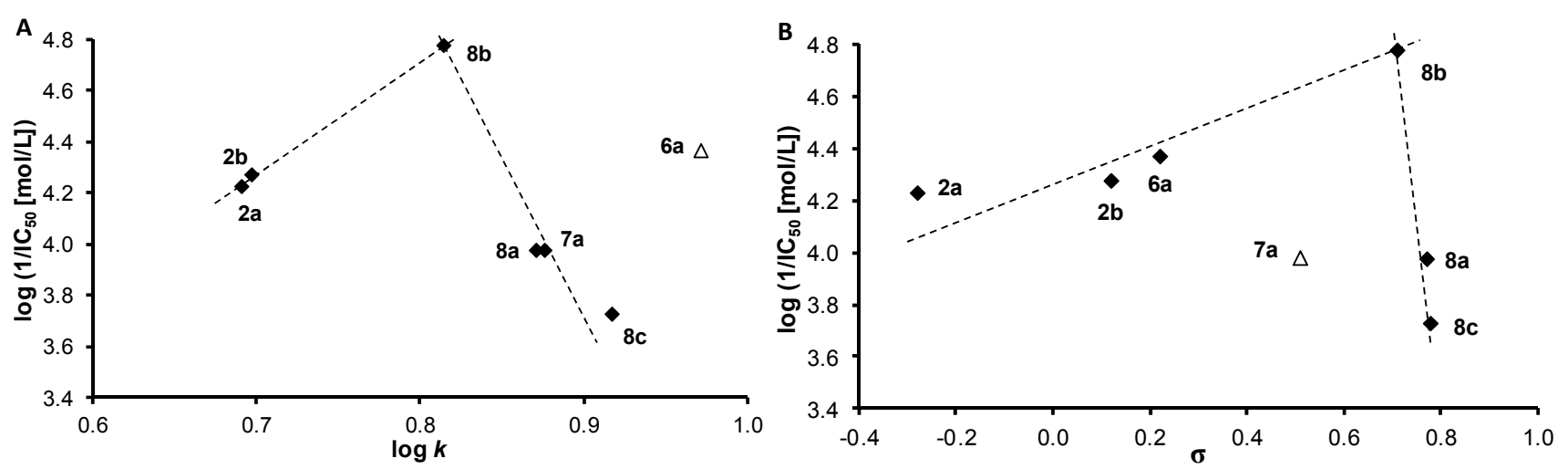

The biological activity is affected by lipophilicity (see Table 1 and Figure 2A). In general, when the inactive anilide, i.e., 6a, was eliminated; the dependence of $\log \left(1 / \mathrm{IC}_{50}[\mathrm{~mol} / \mathrm{L}]\right)$ on $\log k$ is bilinear with the optimum $\log k$ ca. $0.81\left(\mathrm{R}=3-\mathrm{NO}_{2}\right.$, compound $\left.\mathbf{8 b}\right)$. The corresponding correlation coefficients were $r=0.9993$ and $r=-0.9673$. On the other hand, PET inhibition also increases with electron-withdrawing substituent to $\sigma=0.71\left(\mathrm{R}=3-\mathrm{NO}_{2}\right.$, compound $\left.\mathbf{8 b}\right)$, where the optimum can be found, and then decreases with a subsequent increase of electron-withdrawing properties of substituents $\left(\sigma=0.78, \mathrm{R}=4-\mathrm{NO}_{2}\right.$, compound 8c and $\sigma=0.77, \mathrm{R}=2-\mathrm{NO}_{2}$, compound 8a). Thus, when the activity of compound $\mathbf{7 a}$ is not considered, the dependence of PET-inhibiting activity on the electronic $\sigma$ properties of substituents (Figure 2B) shows a similar bilinear trend as in case of $\log k$ 
(Figure 2A), with correlations coefficients $r=0.9313$ (for the $\sigma$ range from -0.28 to 0.71 ) and $r=-0.9956$ for $\sigma>0.71)$.

Using artificial electron donors with the known site of action can help in the determination of inhibitory site of action of the studied compound in photosynthetic apparatus. For example, the artificial electron donor 1,5-diphenylcarbazide (DPC) acts in $\mathrm{Z}^{\bullet} / \mathrm{D}^{\bullet}$ intermediate [38] and by supply of electrons it can restore PET in chloroplasts which was inhibited on the donor side of PS II in the section from the oxygen evolving complex to the $Z^{\bullet} / D^{\bullet}$ intermediate. However, if PET is inhibited at the acceptor side of PS II, PET will not be restored. Application of the artificial electron donor 1,5diphenylcarbazide acting in $\mathrm{Z}^{\bullet} / \mathrm{D}^{\bullet}$ intermediate [38] to chloroplasts the activity of which was inhibited by the studied compounds ( $75 \%$ inhibition related to the control) practically completely restored PET (up to $97.8 \%$ of the control), indicating that PET on the acceptor side of PS II between the core of PS II (P680) and the secondary plastoquinone molecules/acceptor $\mathrm{Q}_{\mathrm{B}}$ was not inhibited by the tested compounds. Consequently, it can be assumed that the site of action of the studied compounds is situated on the donor side of PS II in the section between the primary electron donor of PS II $\left(\mathrm{H}_{2} \mathrm{O}\right)$ and $\mathrm{Z}^{\bullet} / \mathrm{D}^{\bullet}$ intermediate.

The bilinear course of the dependence of $\log \left(1 / \mathrm{IC}_{50}\right)$ on $\sigma$ indicates that for the PET-inhibiting activity not only sufficient lipophilicity (enabling easier penetration of the compounds into the lipids of photosynthetic membranes) but also sufficient electronegativity of the $\mathrm{R}$ substituent (enabling interactions with proteins located near oxygen evolving complex present at the luminal side of thylakoid membrane) is necessary. 3-Hydroxy- $N$-(3-nitrophenyl)naphthalene-2-carboxamide (8b) was the most active compound from the series, and this result can indicate that PET inhibition can be associated with additional interaction of the nitro moiety with photosynthetic proteins, nevertheless the role of the nitro group in the meta-position might originate also from its electron withdrawing properties that influence electron distribution in the aromatic ring. A strong dependence of PETinhibiting activity on $\sigma$ was also found for 2-benzylsulphanylbenzimidazoles [39]. The site of action situated on the donor side of PS II was found also for 2-alkylthio-6-R-benzothiazoles $(\mathrm{R}=6$ formamido-, 6-acetamido-, and 6-benzoylamino-) [40], anilides of 2-alkylpyridine-4-carboxylic acids acting in intermediates $\mathrm{Z}^{\bullet} / \mathrm{D}^{\bullet}$ [41], 5-bromo- $N$-phenylbenzamides [42] and 2-alkylsulphanyl-4pyridinecarbothioamides acting in the $\mathrm{D}^{\bullet}$ intermediate [43].

The effects of the studied compounds on the photosynthetic apparatus of spinach chloroplasts were investigated by studying chlorophyll $a(\mathrm{Chl} a)$ fluorescence. The decreased intensity of the emission band at $686 \mathrm{~nm}$ belonging to the pigment-protein complexes in photosystem II [44] (Figure 3A) suggested PS II as the site of action of the studied inhibitors. Lower solubility of compound $\mathbf{2} \mathbf{b}$ did not allow to record fluorescence emission spectra of chloroplasts treated with compound concentration higher than $0.780 \mathrm{mmol} / \mathrm{L}$. The extent of perturbation of chlorophyll $a$-protein complexes in the thylakoid membrane reflected as decreased fluorescence (Figure 3B) correlated with PET inhibiting activity of compounds $\mathbf{2} \mathbf{b}$ and $\mathbf{7 a}\left(\mathrm{IC}_{50}=53.4\right.$ and $105.2 \mu \mathrm{mol} / \mathrm{L}$, respectively). A similar decrease of Chla fluorescence in plant chloroplasts was observed after treatment with $\mathrm{HgCl}_{2}$ [45], non-ionic surfactant Triton X 100 [46] as well as substituted benzanilides [47] and salicyanilides [48]. 
Figure 3. Fluorescence emission spectra of chlorophyll $a$ in untreated spinach chloroplasts in presence of compound 7a: 0, 0.195, 0.390, 0.780, 1.170 and $1.560 \mathrm{mmol} / \mathrm{L}$ (curves from top to bottom; $\lambda_{\mathrm{ex}}=436 \mathrm{~nm}$ ) (A) and dependence of fluorescence intensity of chlorophyll $a$ on concentration of compounds $\mathbf{2 b}$ (triangles) and $7 \mathbf{a}$ (circles) (B).
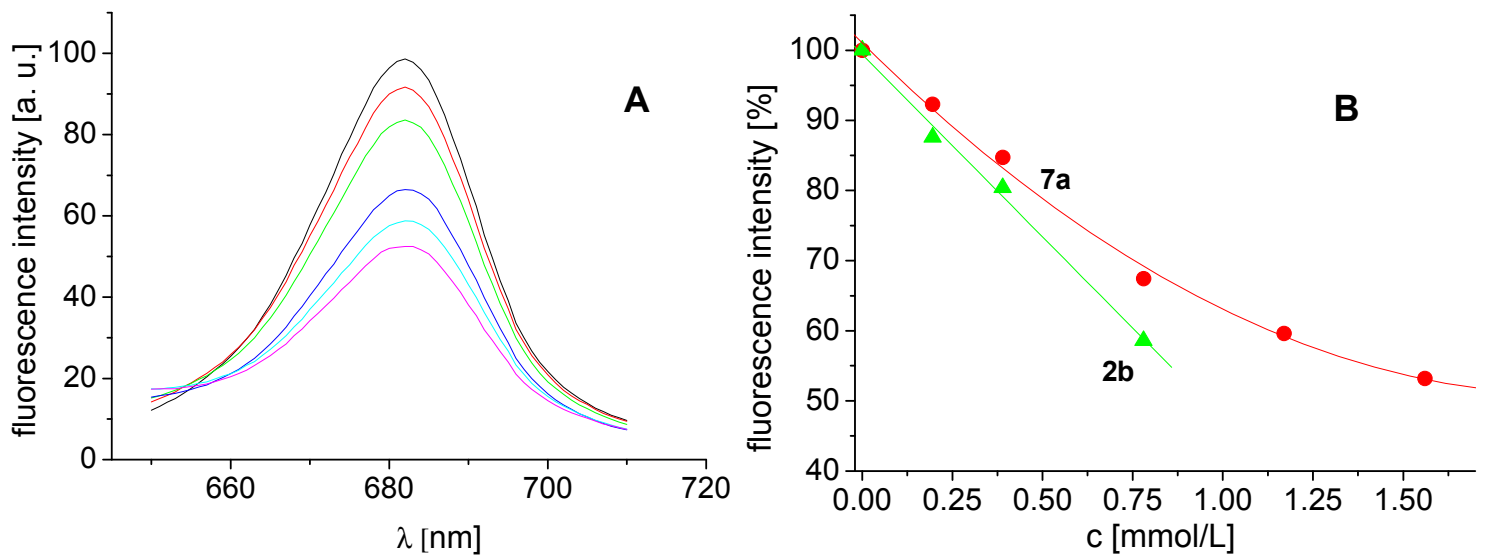

\subsection{In Vitro Antibacterial Susceptibility Testing}

Although salicylanilides seem to be promising candidates of antibacterial agents [31,32], all the compounds showed only moderate activity, except for 3-hydroxy- $N$-(2-methoxyphenyl)naphthalene2-carboxamide (2a). As MIC $=55 \mu \mathrm{mol} / \mathrm{L}$ of compound $\mathbf{2 a}$ was the same for all four strains, it can be speculated about specific effectivity against Staphylococcus sp. From Table 1 it is obvious that compound 2a exhibited activity comparable with the standards. 3-Hydroxy- $N$-(2-trifluoromethylphenyl)naphthalene-2-carboxamide (7a) seems to be another noteworthy compound. Nevertheless due to moderate activity of the rest of the compounds, no thorough SAR could be established.

\subsection{In Vitro Antimycobacterial Evaluation}

Although all the compounds were evaluated for their in vitro antimycobacterial activity against both mycobacterial strains, most of compounds showed only moderate or no activity, see Table 1. Nevertheless $N$-(2-fluorophenyl)-3-hydroxynaphthalene-2-carboxamide (4a) expressed the activity comparable with or higher than the used standard isoniazid against both strains, and 3-hydroxy- $N$ (4-nitrophenyl)naphthalene-2-carboxamide (8c) showed relatively high activity against $M$. kansasii.

According to the results, it can be generally concluded that activity against $M$. marinum can be observed especially for ortho-substituted anilides. When the least active anilides $\mathbf{3 b}$ and $\mathbf{4} \mathbf{c}$ are eliminated, the dependences of activity on $\log k$ and on electronic $\sigma$ properties are bilinear with the optima $\log k$ ca. 0.73 and $\sigma=0.06(\mathrm{R}=2-\mathrm{F}$, compound 4a). After the optima the antimycobacterial activity against $M$. marinum decreases with an increase of lipophilicity and/or electron-withdrawing properties of the R substituent.

Within activity against M. kansasii, it can be generally concluded that for anilides substituted in meta- or para-position by methyl and halogens (except the fluoro moiety) the activity slightly increases with increasing lipophilicity and electron-withdrawing properties. For ortho-substituted anilides similar bilinear relationships can be found, as discussed above, with the optima $\log k$ ca. 0.73 and $\sigma=0.06(\mathrm{R}=2-\mathrm{F}$, compound $4 \mathbf{a})$. 


\subsection{In Vitro Cytotoxicity Assay}

The most effective compounds $\mathbf{2 a}, \mathbf{2 b}, \mathbf{3 b}, \mathbf{4 a}, \mathbf{7 a}, \mathbf{8 b}$ and $\mathbf{8 c}$ were tested for their in vitro cytotoxicity $\mathrm{LD}_{50}(\mu \mathrm{mol} / \mathrm{L})$ using human monocytic leukemia THP-1 cells. These cells were used, because they represent human cell line [49]. In the past several works were published, where the toxicity of tested compounds (including antibacterial agents [20,50]) was assessed on THP-1 cells. The highest dose of compounds $\mathbf{2} \mathbf{a}, \mathbf{b}\left(\mathrm{R}=2-, 3-\mathrm{OCH}_{3}\right), \mathbf{3 b}\left(\mathrm{R}=3-\mathrm{CH}_{3}\right)$ and $\mathbf{4 a}(\mathrm{R}=2-\mathrm{F})$ in the medium (30 $\mu \mathrm{mol} / \mathrm{L}$, it was not possible to solve higher amount) did not lead to significant lethal effect on THP-1 cells, i.e., $\mathrm{LD}_{50}>30 \mu \mathrm{mol} / \mathrm{L}$. Compound $7 \mathbf{a}\left(2-\mathrm{CF}_{3}\right)$ demonstrated low toxicity $\left(\mathrm{LD}_{50}=28.6 \pm 0.5 \mu \mathrm{mol} / \mathrm{L}\right)$ against the human monocytic leukemia THP-1 cell line. Compounds containing 3- $\mathrm{NO}_{2}(\mathbf{8 b})$ and $4-\mathrm{NO}_{2}(\mathbf{8 c})$ exerted fairly high toxicity $\mathrm{LD}_{50}=2.5 \pm 0.9 \mu \mathrm{mol} / \mathrm{L}$ for $\mathbf{8 b}$ and $\mathrm{LD}_{50}<0.37 \mu \mathrm{mol} / \mathrm{L}$ for $\mathbf{8 c}$ (for example, $\mathrm{LD}_{50}$ of oxaliplatin and camptothecin assessed in this line formerly were much lower: $1.7 \pm 0.6 \mu \mathrm{mol} / \mathrm{L}$ and $0.20 \pm 0.07 \mu \mathrm{mol} / \mathrm{L}$ respectively), which correlates with the positions of these substituents: toxicity increased with the shift of $\mathrm{NO}_{2}$ moiety from ortho to para position ( $\mathbf{8 b}$ is less toxic than $\mathbf{8 c}$ ). Based on these observations it can be concluded that the discussed amides $\mathbf{2 a}, \mathbf{2} \mathbf{b}, \mathbf{3 b}$ and $\mathbf{4 a}$ can be considered as promising agents for subsequent design of novel antibacterial and antimycobacterial agents, respectively.

\section{Experimental}

\subsection{General}

All reagents were purchased from Aldrich (Sigma-Aldrich, St. Louis, MO, USA). TLC experiments were performed on alumina-backed silica gel 40 F254 plates (Merck, Darmstadt, Germany). The plates were illuminated under UV (254 nm) and evaluated in iodine vapour. The melting points were determined on Kofler hot-plate apparatus HMK (Franz Kustner Nacht KG, Dresden, Germany) and are uncorrected. Infrared (IR) spectra were recorded on a Smart MIRacle ${ }^{\mathrm{TM}}$ ATR ZnSe for Nicolet ${ }^{\mathrm{TM}}$ Impact 410 FT-IR spectrometer (Thermo Electron Corporation, West Palm Beach, FL, USA). The spectra were obtained by accumulation of 256 scans with $2 \mathrm{~cm}^{-1}$ resolution in the region of 4000-600 $\mathrm{cm}^{-1}$. All ${ }^{1} \mathrm{H}$ - and ${ }^{13} \mathrm{C}-\mathrm{NMR}$ spectra were recorded on a Bruker Avance III $400 \mathrm{MHz}$ FT-NMR spectrometer (400 MHz for ${ }^{1} \mathrm{H}$ and $100 \mathrm{MHz}$ for ${ }^{13} \mathrm{C}$, Bruker Comp., Karlsruhe, Germany). Chemicals shifts are reported in ppm $(\delta)$ using internal $\mathrm{Si}\left(\mathrm{CH}_{3}\right)_{4}$ as the reference with diffuse, easily exchangeable signals being omitted. Mass spectra were measured using a LTQ Orbitrap Hybrid Mass Spectrometer (Thermo Electron Corporation) with direct injection into an APCI source $\left(400{ }^{\circ} \mathrm{C}\right)$ in the positive mode. The purity of the compounds was checked by the HPLC method using the same conditions as described in Section 3.3. The detection wavelength of $210 \mathrm{~nm}$ was chosen. The peaks in the chromatogram of the solvent (blank) were deducted from the peaks in the chromatogram of the sample solution. A purity of individual compounds was determined from area peaks in the chromatogram of the sample solution. 


\subsection{Synthesis}

\subsubsection{General Procedure for Synthesis of Carboxamide Derivatives 1-8c}

3-Hydroxynaphtalene-2-carboxylic acid $(1.0 \mathrm{~g}, 5.3 \mathrm{mmol})$ was suspended in dry chlorobenzene $(30 \mathrm{~mL})$ at ambient temperature and phosphorus trichloride $(0.23 \mathrm{~mL}, 2.7 \mathrm{mmol}, 0.5 \mathrm{eq}$.$) , and the$ corresponding substituted aniline $(5.3 \mathrm{mmol}, 1$ eq.) was added dropwise. The reaction mixture was transferred to the microwave reactor, where the synthesis was performed ( 1 st phase: $10 \mathrm{~min}, 100{ }^{\circ} \mathrm{C}$, $100 \mathrm{~W}$; 2nd phase: $15 \mathrm{~min}, 120^{\circ} \mathrm{C}, 500 \mathrm{~W}$; $3 \mathrm{rd}$ phase: $20 \mathrm{~min}, 130{ }^{\circ} \mathrm{C}, 500 \mathrm{~W}$ ). Then the mixture was cooled to $60{ }^{\circ} \mathrm{C}$, and then the solvent was removed to dryness under reduced pressure. The residue was washed with hydrochloride acid and water. The crude product was recrystallized from EtOH. Studied compounds $\mathbf{1}-\mathbf{8 c}$ are presented in Table 1.

3-Hydroxy-N-phenylnaphthalene-2-carboxamide (1). Yield 76\%; Mp. 245-246 ${ }^{\circ} \mathrm{C}$ (Mp. 242-243 ${ }^{\circ} \mathrm{C}$ [34]); HPLC purity 99.41\%; IR (Zn/Se ATR, $\left.\mathrm{cm}^{-1}\right)$ : 3291w, 1620m, 1556m,1494w, 1448w, 1396w, $1344 \mathrm{~m}, 1250 \mathrm{w}, 1209 \mathrm{~m}, 1173 \mathrm{~m}, 1064 \mathrm{w}, 950 \mathrm{w}, 915 \mathrm{w}, 870 \mathrm{~m}, 842 \mathrm{~m}, 771 \mathrm{w}, 739 \mathrm{~s}, 712 \mathrm{~m}, 687 \mathrm{~m} ;{ }^{1} \mathrm{H}-$ NMR (DMSO- $\left.d_{6}\right), \delta: 11.36(\mathrm{~s}, 1 \mathrm{H}), 10.60(\mathrm{~s}, 1 \mathrm{H}), 8.53(\mathrm{~s}, 1 \mathrm{H}), 7.93(\mathrm{~d} J=8.1 \mathrm{~Hz}, 1 \mathrm{H}), 7.78(\mathrm{~m}, 3 \mathrm{H})$, $7.51(\mathrm{ddd}, J=8.1 \mathrm{~Hz}, J=6.8 \mathrm{~Hz}, J=1.3 \mathrm{~Hz}, 1 \mathrm{H}), 7.44-7.33(\mathrm{~m}, 4 \mathrm{H}), 7.15(\mathrm{t}, J=7.26 \mathrm{~Hz}, 1 \mathrm{H}) ;{ }^{13} \mathrm{C}-$ NMR (DMSO- $\left.d_{6}\right), \delta: 165.67,153.79,138.37,135.76,130.42,128.72,128.66,128.08,126.83,125.72$, 124.03, 123.69, 121.55, 120.55, 110.57; HR-MS: for $\mathrm{C}_{17} \mathrm{H}_{14} \mathrm{NO}_{2}[\mathrm{M}+\mathrm{H}]^{+}$calculated $264.1019 \mathrm{~m} / z$, found $264.1023 \mathrm{~m} / \mathrm{z}$.

3-Hydroxy-N-(2-methoxyphenyl)naphthalene-2-carboxamide (2a). Yield 80\%; Mp. 165-166 ${ }^{\circ} \mathrm{C}$ (Mp. 164-166 ${ }^{\circ} \mathrm{C}$ [34]); HPLC purity 99.28\%; IR (Zn/Se ATR, $\left.\mathrm{cm}^{-1}\right): 3191 \mathrm{w}, 1624 \mathrm{~m}, 1593 \mathrm{~s}, 1549 \mathrm{~m}$, $1487 \mathrm{w}, 1435 \mathrm{~m}, 1393 \mathrm{w}, 1393 \mathrm{w}, 1342 \mathrm{~m}, 1284 \mathrm{~m}, 1248 \mathrm{w}, 1227 \mathrm{~m}, 1173 \mathrm{~m}, 1115 \mathrm{~m}, 1067 \mathrm{~m}, 1031 \mathrm{w}$, 922w, 864m, 837m, 801w, 771m, 735s, 685m; ${ }^{1} \mathrm{H}-\mathrm{NMR}$ (DMSO-d $), \delta: 11.78(\mathrm{~s}, 1 \mathrm{H}), 11.08(\mathrm{~s}, 1 \mathrm{H})$, $8.72(\mathrm{~s}, 1 \mathrm{H}), 8.51(\mathrm{~d}, J=7.7 \mathrm{~Hz}, 1 \mathrm{H}), 7.98(\mathrm{~d}, J=8.1 \mathrm{~Hz}, 1 \mathrm{H}), 7.77(\mathrm{~d}, J=8.1 \mathrm{~Hz}, 1 \mathrm{H}), 7.51$ (ddd, $J=8.1 \mathrm{~Hz}, J=6.8 \mathrm{~Hz}, J=0.9 \mathrm{~Hz}, 1 \mathrm{H}), 7.40-7.32(\mathrm{~m}, 2 \mathrm{H}), 7.11-6.92(\mathrm{~m}, 3 \mathrm{H}), 3.92(\mathrm{~s}, 3 \mathrm{H})$; ${ }^{13} \mathrm{C}-\mathrm{NMR}\left(\mathrm{DMSO}-d_{6}\right), \delta: 162.27,152.61,148.64,135.82,132.50,128.94,128.22,127.91,127.19$, 125.58, 123.94, 123.79, 121.29, 120.62, 120.19, 111.01, 110.71, 56.05; HR-MS: for $\mathrm{C}_{18} \mathrm{H}_{16} \mathrm{NO}_{3}$ $[\mathrm{M}+\mathrm{H}]^{+}$calculated $294.1124 \mathrm{~m} / \mathrm{z}$, found $294.1130 \mathrm{~m} / \mathrm{z}$.

3-Hydroxy-N-(3-methoxyphenyl)naphthalene-2-carboxamide (2b). Yield 75\%; Mp. 194-195 ${ }^{\circ} \mathrm{C}$; HPLC purity 99.05\%; IR (Zn/Se ATR, $\left.\mathrm{cm}^{-1}\right): 3316 w, 3047 \mathrm{w}, 1642 \mathrm{~m}, 1622 \mathrm{~s}, 1593 \mathrm{~s}, 1556 \mathrm{~s}, 1456 \mathrm{~m}$, $1398 \mathrm{w}, 1365 \mathrm{w}, 1346 \mathrm{w}, 1266 \mathrm{~m}, 1225 \mathrm{~m}, 1157 \mathrm{~m}, 1134 \mathrm{w}, 1067 \mathrm{~m}, 1046 \mathrm{~s}, 962 \mathrm{w}, 913 \mathrm{~m}, 873 \mathrm{~s}, 799 w$, 770m, 752m, 682m; ${ }^{1} \mathrm{H}-\mathrm{NMR}\left(\mathrm{DMSO}-d_{6}\right), \delta: 11.30(\mathrm{~s}, 1 \mathrm{H}), 10.56(\mathrm{~s}, 1 \mathrm{H}), 8.51(\mathrm{~s}, 1 \mathrm{H}), 7.93(\mathrm{~d}$, $J=8.1 \mathrm{~Hz}, 1 \mathrm{H}), 7.77(\mathrm{~d}, J=8.1 \mathrm{~Hz}, 1 \mathrm{H}), 7.55-7.47(\mathrm{~m}, 2 \mathrm{H}), 7.40-7.24(\mathrm{~m}, 4 \mathrm{H}), 6.76-6.70(\mathrm{~m}, 1 \mathrm{H})$, $3.78(\mathrm{~s}, 3 \mathrm{H}) ;{ }^{13} \mathrm{C}-\mathrm{NMR}$ (DMSO- $d_{6}$ ), $\delta: 165.64,159.52,153.67,139.58,135.73,130.42,129.50$, 128.64, 128.06, 126.83, 125.72, 123.69, 121.75, 112.72, 110.54, 109.50, 106.28, 55.03; HR-MS: for $\mathrm{C}_{18} \mathrm{H}_{16} \mathrm{NO}_{3}[\mathrm{M}+\mathrm{H}]^{+}$calculated $294.1124 \mathrm{~m} / \mathrm{z}$, found $294.1131 \mathrm{~m} / \mathrm{z}$.

3-Hydroxy-N-(4-methoxyphenyl)naphthalene-2-carboxamide (2c). Yield 66\%; Mp. 235-236 ${ }^{\circ} \mathrm{C}$; HPLC purity 99.53\%; IR (Zn/Se ATR, $\left.\mathrm{cm}^{-1}\right)$ : 3283w, 3013w, 1636m, 1618s, 1564m, 1510m, 1393w, $1357 \mathrm{~m}, 1303 \mathrm{w}, 1247 \mathrm{~m}, 1170 \mathrm{~m}, 1146 \mathrm{w}, 1116 \mathrm{w}, 1070 \mathrm{~m}, 1030 \mathrm{~m}, 950 \mathrm{~m}, 878 \mathrm{~m}, 856 \mathrm{~m}, 830 \mathrm{~s}, 795 \mathrm{w}$, 775w, 737m; ${ }^{1} \mathrm{H}-\mathrm{NMR}\left(\mathrm{DMSO}-d_{6}\right), \delta: 11.47$ (s, 1H), $10.50(\mathrm{~s}, 1 \mathrm{H}), 8.56(\mathrm{~s}, 1 \mathrm{H}), 7.92(\mathrm{~d}, J=7.7 \mathrm{~Hz}$, 
$1 \mathrm{H}), 7.76(\mathrm{~d}, J=8.6 \mathrm{~Hz}, 1 \mathrm{H}), 7.71-7.64(\mathrm{~m}, 2 \mathrm{H}), 7.51(\mathrm{ddd}, J=8.1 \mathrm{~Hz}, J=6.8 \mathrm{~Hz}, J=1.3 \mathrm{~Hz}, 1 \mathrm{H})$, 7.40-7.33 (m, 2H), 7.01-6.93 (m, 2H), 3.77 (s, 3H); ${ }^{13} \mathrm{C}-\mathrm{NMR}$ (DMSO-d $), \delta: 165.65,155.91,154.18$, $135.78,131.25,130.12,128.62,128.06,126.75,125.70,123.64,122.31,120.87,113.87,110.59$, 55.16; HR-MS: for $\mathrm{C}_{18} \mathrm{H}_{16} \mathrm{NO}_{3}[\mathrm{M}+\mathrm{H}]^{+}$calculated $294.1124 \mathrm{~m} / \mathrm{z}$, found $294.1130 \mathrm{~m} / \mathrm{z}$.

3-Hydroxy-N-(2-methylphenyl)naphthalene-2-carboxamide (3a). Yield 74\%; Mp. 195-196 ${ }^{\circ} \mathrm{C}$ (Mp. 194-196 ${ }^{\circ} \mathrm{C}$ [34]); HPLC purity 98.84\%; IR (Zn/Se ATR, $\left.\mathrm{cm}^{-1}\right): 3325 \mathrm{w}, 3115 \mathrm{w}, 1622 \mathrm{~s}, 1586 \mathrm{~m}$, $1548 \mathrm{~m}, 1456 \mathrm{~m}, 1385 \mathrm{w}, 1355 \mathrm{w}, 1356 \mathrm{w}, 1248 \mathrm{w}, 1173 \mathrm{~m}, 1065 \mathrm{~m}, 954 \mathrm{w}, 915 \mathrm{w}, 873 \mathrm{~m}, 844 \mathrm{w}, 803 \mathrm{w}, 773 w$, 742s, 679m; ${ }^{1} \mathrm{H}-\mathrm{NMR}$ (DMSO-d ${ }_{6}$ ), $\delta: 11.80(\mathrm{~s}, 1 \mathrm{H}), 10.53(\mathrm{~s}, 1 \mathrm{H}), 8.69(\mathrm{~s}, 1 \mathrm{H}), 7.96(\mathrm{~d}, J=7.7 \mathrm{~Hz}, 2 \mathrm{H})$, $7.78(\mathrm{~d}, J=8.1 \mathrm{~Hz}, 1 \mathrm{H}), 7.52(\mathrm{ddd}, J=8.1 \mathrm{~Hz}, J=6.8 \mathrm{~Hz}, J=1.3 \mathrm{~Hz}, 1 \mathrm{H}), 7.41-7.36(\mathrm{~m}, 2 \mathrm{H}), 7.33-$ $7.22(\mathrm{~m}, 2 \mathrm{H}), 7.16-7.08(\mathrm{~m}, 1 \mathrm{H}), 2.34(\mathrm{~s}, 3 \mathrm{H})$; ${ }^{13} \mathrm{C}-\mathrm{NMR}$ (DMSO-d $), \delta: 164,58,153.57,136.36$, $135.87,131.45,130.29$, 129.99, 128.82, 128.22, 126.99, 126.24, 125.67, 124.86, 123.76, 123.36, 120.60, 110.72, 17.73; HR-MS: for $\mathrm{C}_{18} \mathrm{H}_{16} \mathrm{NO}_{2}[\mathrm{M}+\mathrm{H}]^{+}$calculated $278.1176 \mathrm{~m} / \mathrm{z}$, found $278.1182 \mathrm{~m} / \mathrm{z}$.

3-Hydroxy-N-(3-methylphenyl)naphthalene-2-carboxamide (3b). Yield 73\%; Mp. 207-208 ${ }^{\circ} \mathrm{C}$; HPLC purity $98.73 \%$; IR $\left(\mathrm{Zn} / \mathrm{Se}\right.$ ATR, $\left.\mathrm{cm}^{-1}\right)$ : 3297w, 3048w, 1607s, $1557 \mathrm{~m}, 1489 \mathrm{~m}, 1451 \mathrm{w}, 1397 \mathrm{w}, 1357 \mathrm{w}$, $1344 \mathrm{w}, 1259 \mathrm{~m}, 1210 \mathrm{~m}, 1173 \mathrm{w}, 1076 \mathrm{w}, 951 \mathrm{~m}, 923 \mathrm{~m}, 859 \mathrm{~s}, 836 \mathrm{~m}, 783 \mathrm{~s}, 744 \mathrm{~s}, 689 \mathrm{~s} ;{ }^{1} \mathrm{H}-\mathrm{NMR}$ $\left(\mathrm{DMSO}_{-}\right), \delta: 11.38(\mathrm{~s}, 1 \mathrm{H}), 10.53(\mathrm{~s}, 1 \mathrm{H}), 8.54(\mathrm{~s}, 1 \mathrm{H}), 7.93(\mathrm{~d}, J=8.6 \mathrm{~Hz}, 1 \mathrm{H}), 7.77$ (d, $J=8.1 \mathrm{~Hz}$, 1H), 7.60-7.47 (m, 3H), 7.40-7.32 (m, 2H), $7.27(\mathrm{t}, J=7.7 \mathrm{~Hz}, 1 \mathrm{H}), 6.97(\mathrm{~d}, J=7.3 \mathrm{~Hz}, 1 \mathrm{H}), 2.34$ $(\mathrm{s}, 3 \mathrm{H}) ;{ }^{13} \mathrm{C}-\mathrm{NMR}$ (DMSO- $d_{6}$ ), $\delta: 165.62,153.84,138.26,137.96,135.77,130.42,128.66,128.56$, $128.08,126.82,125.71,124.74,123.69,121.40,121.06,117.73,110.59 ; 21.11$; HR-MS: for $\mathrm{C}_{18} \mathrm{H}_{16} \mathrm{NO}_{2}[\mathrm{M}+\mathrm{H}]^{+}$calculated $278.1176 \mathrm{~m} / \mathrm{z}$, found $278.1181 \mathrm{~m} / \mathrm{z}$.

3-Hydroxy-N-(4-methylphenyl)naphthalene-2-carboxamide (3c). Yield 68\%; Mp. 220-221 ${ }^{\circ} \mathrm{C}$ (Mp. $221{ }^{\circ} \mathrm{C}$ [35]); HPLC purity 99.56\%; IR (Zn/Se ATR, $\left.\mathrm{cm}^{-1}\right): 3290 \mathrm{w}, 3008 \mathrm{w}, 1619 \mathrm{~s}, 1556 \mathrm{~m}, 1516 \mathrm{w}$, $1450 \mathrm{w}, 1357 \mathrm{~m}, 1252 \mathrm{~m}, 1208 \mathrm{~m}, 1175 \mathrm{~m}, 1121 \mathrm{w}, 1070 \mathrm{~m}, 951 \mathrm{~m}, 913 \mathrm{~m}, 869 \mathrm{~s}, 832 \mathrm{~m}, 810 \mathrm{~s}, 761 \mathrm{w}, 741 \mathrm{~s}$, 716s; ${ }^{1} \mathrm{H}-\mathrm{NMR}$ (DMSO- $\left.d_{6}\right), \delta: 11.46(\mathrm{~s}, 1 \mathrm{H}), 10.57(\mathrm{~s}, 1 \mathrm{H}), 8.55(\mathrm{~s}, 1 \mathrm{H}), 7.93(\mathrm{~d}, J=8.1 \mathrm{~Hz}, 1 \mathrm{H}), 7.77$ $(\mathrm{d}, J=8.1 \mathrm{~Hz}, 1 \mathrm{H}), 7.67(\mathrm{~d}, J=8.6 \mathrm{~Hz}, 2 \mathrm{H}), 7.51(\mathrm{ddd}, J=8.1 \mathrm{~Hz}, J=6.8 \mathrm{~Hz}, J=1.3 \mathrm{~Hz}, 1 \mathrm{H})$, $7.40-7.32(\mathrm{~m}, 2 \mathrm{H}), 7.19(\mathrm{~d}, J=8.6 \mathrm{~Hz}, 2 \mathrm{H}), 2.29$ (s, 3H); ${ }^{13} \mathrm{C}-\mathrm{NMR}$ (DMSO-d $), \delta: 165.64,154.01$, $135.78,133.12,130.32,129.10,128.64,128.06,126.80,125.70,123.66,121.16,120.62,110.60$, 20.42; HR-MS: for $\mathrm{C}_{18} \mathrm{H}_{16} \mathrm{NO}_{2}[\mathrm{M}+\mathrm{H}]^{+}$calculated $278.1176 \mathrm{~m} / \mathrm{z}$, found $278.1182 \mathrm{~m} / \mathrm{z}$.

N-(2-Fluorophenyl)-3-hydroxynaphthalene-2-carboxamide (4a). Yield 65\%; Mp. 222-223 ${ }^{\circ} \mathrm{C}$ (Mp. 226-228 ${ }^{\circ} \mathrm{C}$ [36]); HPLC purity 97.21\%; IR (Zn/Se ATR, $\left.\mathrm{cm}^{-1}\right): 2981 \mathrm{w}, 1625 \mathrm{~s}, 1605 \mathrm{~s}, 1556 \mathrm{~m}$, $1488 \mathrm{w}, 1458 \mathrm{~m}, 1345 \mathrm{~m}, 1262 \mathrm{~m}, 1219 \mathrm{~m}, 1206 \mathrm{w}, 1191 \mathrm{w}, 1102 \mathrm{w}, 1065 \mathrm{~m}, 1033 \mathrm{~m}, 951 w, 916 \mathrm{e}, 867 \mathrm{~m}$, 838w, 811m, 774w, 740s, 693w; ${ }^{1} \mathrm{H}-\mathrm{NMR}$ (DMSO- $d_{6}$ ), $\delta: 11.86(\mathrm{~s}, 1 \mathrm{H}), 10.95(\mathrm{~s}, 1 \mathrm{H}), 8.69(\mathrm{~s}, 1 \mathrm{H})$, $8.36(\mathrm{dt}, J=7.7 \mathrm{~Hz}, J=2.2 \mathrm{~Hz}, 1 \mathrm{H}), 7.98(\mathrm{~d}, J=8.1 \mathrm{~Hz}, 1 \mathrm{H}), 7.78(\mathrm{~d}, J=7.7 \mathrm{~Hz}, 1 \mathrm{H}), 7.52$ (ddd, $J=8.1 \mathrm{~Hz}, J=6.8 \mathrm{~Hz}, J=1.3 \mathrm{~Hz}, 1 \mathrm{H}), 7.41-7.33(\mathrm{~m}, 2 \mathrm{H}), 7.30-7.25(\mathrm{~m}, 1 \mathrm{H}), 7.24-7.16(\mathrm{~m}, 2 \mathrm{H})$; ${ }^{13} \mathrm{C}-\mathrm{NMR}\left(\mathrm{DMSO}-d_{6}\right), \delta: 163.90,153.08,(\mathrm{~d}, J=243.8 \mathrm{~Hz}), 152.88,135.97,132.17,128.93,128.03$, 127.08, 126.27 (d, $J=10.7 \mathrm{~Hz}), 125.66,124.98$ (d, $J=6.9 \mathrm{~Hz}), 124.62(\mathrm{~d}, J=3.4 \mathrm{~Hz}), 123.88,122.87$ $(\mathrm{d}, J=0.8 \mathrm{~Hz}), 120.46,115.18(\mathrm{~d}, J=19.1 \mathrm{~Hz}), 110.81$; HR-MS: for $\mathrm{C}_{17} \mathrm{H}_{13} \mathrm{FNO}_{2}[\mathrm{M}+\mathrm{H}]^{+}$calculated $282.0925 \mathrm{~m} / \mathrm{z}$, found $282.0931 \mathrm{~m} / \mathrm{z}$.

N-(3-Fluorophenyl)-3-hydroxynaphthalene-2-carboxamide (4b). Yield 67\%; Mp. 248-249 ${ }^{\circ} \mathrm{C}$; HPLC purity $97.78 \%$; IR (Zn/Se ATR, $\left.\mathrm{cm}^{-1}\right): 3305 \mathrm{w}, 3033 \mathrm{w}, 1622 \mathrm{~s}, 1557 \mathrm{w}, 1516 \mathrm{w}, 1489 \mathrm{w}, 1449 \mathrm{w}, 1401 \mathrm{w}$, 
$1361 \mathrm{w}, 1334 \mathrm{w}, 1253 \mathrm{~m}, 1212 \mathrm{~s}, 1178 \mathrm{~m}, 952 \mathrm{~m}, 915 \mathrm{~m}, 872 \mathrm{~m}, 840 \mathrm{~s} 771 \mathrm{~m}, 742 \mathrm{~s}, 715 \mathrm{~m}, 685 \mathrm{~m} ;{ }^{1} \mathrm{H}-\mathrm{NMR}$ $\left(\mathrm{DMSO}_{6}\right), \delta: 11.19(\mathrm{~s}, 1 \mathrm{H}), 10.73(\mathrm{~s}, 1 \mathrm{H}), 8.45(\mathrm{~s}, 1 \mathrm{H}), 7.93(\mathrm{~d}, J=7.7 \mathrm{~Hz}, 1 \mathrm{H}), 7.82(\mathrm{t}, J=2.1 \mathrm{~Hz}$, 1H), 7.79-7.75 (m, 1H), $7.51(\mathrm{t}, J=7.1 \mathrm{~Hz}, 2 \mathrm{H}), 7.44-7.32(\mathrm{~m}, 3 \mathrm{H}), 7.02-6.92(\mathrm{~m}, 1 \mathrm{H}) ;{ }^{13} \mathrm{C}-\mathrm{NMR}$ (DMSO-d $d_{6}$ ), $\delta: 165.70,162.09(\mathrm{~d}, J=241.5 \mathrm{~Hz}), 153.38,140.24(\mathrm{~d}, J=11.1 \mathrm{~Hz}), 135.73,130.54$, 130.48, 130.30 (d, $J=9.5 \mathrm{~Hz}), 128.63,128.08,126.84,125.73,123.71,122.09,116.06$ (d, $J=2.7 \mathrm{~Hz})$, $110.32(\mathrm{~d}, J=18.7 \mathrm{~Hz}), 107.10\left(\mathrm{~d}, J=25.9 \mathrm{~Hz}\right.$ ); HR-MS: for $\mathrm{C}_{17} \mathrm{H}_{13} \mathrm{FNO}_{2}[\mathrm{M}+\mathrm{H}]^{+}$calculated $282.0925 \mathrm{~m} / \mathrm{z}$, found $282.0932 \mathrm{~m} / \mathrm{z}$.

N-(4-Fluorophenyl)-3-hydroxynaphthalene-2-carboxamide (4c). Yield 69\%; Mp. 264-265 ${ }^{\circ} \mathrm{C}$ (Mp. 264.5-265.5 ${ }^{\circ} \mathrm{C}$ [36]); HPLC purity 98.03\%; IR (Zn/Se ATR, $\left.\mathrm{cm}^{-1}\right): 3289 \mathrm{w}, 2994 \mathrm{w}, 1615 \mathrm{~s}, 1569 \mathrm{~m}$, $1505 \mathrm{~m}, 1445 \mathrm{w}, 1409 \mathrm{w}, 1357 \mathrm{~m}, 1250 \mathrm{w}, 1206 \mathrm{~m}, 1171 \mathrm{w}, 1100 \mathrm{~m}, 1068 \mathrm{~m}, 1011 \mathrm{w}, 952 \mathrm{w}, 915 \mathrm{~m}, 871 \mathrm{~m}$, 829s, 799m, 766m, 739m, 706m; ${ }^{1} \mathrm{H}-\mathrm{NMR}$ (DMSO-d $), \delta: 11.31(\mathrm{~s}, 1 \mathrm{H}), 10.64(\mathrm{~s}, 1 \mathrm{H}), 8.49(\mathrm{~s}, 1 \mathrm{H})$, $7.93(\mathrm{~d}, J=8.12 \mathrm{~Hz}, 1 \mathrm{H}), 7.83-7.75(\mathrm{~m}, 3 \mathrm{H}), 7.51(\mathrm{ddd}, J=8.1 \mathrm{~Hz}, J=6.8 \mathrm{~Hz}, J=1.3 \mathrm{~Hz}, 1 \mathrm{H})$, $7.40-7.32(\mathrm{~m}, 2 \mathrm{H}), 7.23(\mathrm{t}, J=9.0 \mathrm{~Hz}, 2 \mathrm{H}) ;{ }^{13} \mathrm{C}-\mathrm{NMR}$ (DMSO- $\left.d_{6}\right), \delta: 165.71,158.50(\mathrm{~d}, J=240.7 \mathrm{~Hz})$, $153.79,135.76,134.72(\mathrm{~d}, J=2.7 \mathrm{~Hz}), 130.29,128.62,128.06,126.79,125.72,123.68,122.44(\mathrm{~d}, J=8.0$ $\mathrm{Hz}), 121.47,115.28(\mathrm{~d}, J=22.1 \mathrm{~Hz}), 110.55$; HR-MS: for $\mathrm{C}_{17} \mathrm{H}_{13} \mathrm{FNO}_{2}[\mathrm{M}+\mathrm{H}]^{+}$calculated 282.0925 $\mathrm{m} / \mathrm{z}$, found $282.0930 \mathrm{~m} / \mathrm{z}$.

N-(2-Chlorophenyl)-3-hydroxynaphthalene-2-carboxamide (5a). Yield 50\%; Mp. 226-227 ${ }^{\circ} \mathrm{C}$ (Mp. $225^{\circ} \mathrm{C}$ [35]); HPLC purity 98.70\%; IR (Zn/Se ATR, $\left.\mathrm{cm}^{-1}\right): 3164 \mathrm{w}, 1625 \mathrm{~m}, 1591 \mathrm{~s}, 1546 \mathrm{~s}, 1439 \mathrm{~m}$, 1345m, 1293w, 1243w, 1192m, 1171m, 1034m, 840m, 740s, 668m; ${ }^{1} \mathrm{H}-\mathrm{NMR}$ (DMSO-d $_{6}$, $\delta: 11.91$ (s, $1 \mathrm{H}), 11.13(\mathrm{~s}, 1 \mathrm{H}), 8.73(\mathrm{~s}, 1 \mathrm{H}), 8.51(\mathrm{dd}, J=8.1 \mathrm{~Hz}, J=1.3 \mathrm{~Hz}, 1 \mathrm{H}), 7.99(\mathrm{~d}, J=7.69 \mathrm{~Hz}, 1 \mathrm{H}), 7.78$ $(\mathrm{d}, J=8.12 \mathrm{~Hz}, 1 \mathrm{H}), 7.59-7.52(\mathrm{~m}, 2 \mathrm{H}), 7.49-7.45(\mathrm{~m}, 1 \mathrm{H}), 7.41-7.33(\mathrm{~m}, 2 \mathrm{H}), 7.22-7.14(\mathrm{~m}, 1 \mathrm{H})$ ${ }^{13} \mathrm{C}-\mathrm{NMR}$ (DMSO- $d_{6}$ ), $\delta: 163.49,152.65,135.99,135.29,132.62,129.29,128.99,128.42,127.77$, 127.13, 125.62, 125.12, 123.88, 123.35, 122.69, 120.55, 110.78; HR-MS: for $\mathrm{C}_{17} \mathrm{H}_{13} \mathrm{ClNO}_{2}[\mathrm{M}+\mathrm{H}]^{+}$ calculated $298.0629 \mathrm{~m} / \mathrm{z}$, found $298.0637 \mathrm{~m} / \mathrm{z}$.

$\mathrm{N}$-(3-Chlorophenyl)-3-hydroxynaphthalene-2-carboxamide (5b). Yield 69\%; Mp. 257-258 ${ }^{\circ} \mathrm{C}$ (Mp. 258-261 ${ }^{\circ} \mathrm{C}$ [37]); HPLC purity 98.82\%; IR (Zn/Se ATR, $\left.\mathrm{cm}^{-1}\right): 3299 \mathrm{w}, 3054 \mathrm{w}, 1623 \mathrm{~s}, 1545 \mathrm{~m}$, $1476 \mathrm{w}, 1426 \mathrm{~m} \mathrm{1364m,1278w,} \mathrm{1248m,} \mathrm{1214m,} \mathrm{1174w,} \mathrm{1065w,} \mathrm{913w,} \mathrm{866m,} \mathrm{776m,} \mathrm{744m,} \mathrm{708m,}$ 680m; ${ }^{1} \mathrm{H}-\mathrm{NMR}$ (DMSO- $d_{6}$ ), $\delta: 11.16(\mathrm{~s}, 1 \mathrm{H}) ; 10.68(\mathrm{~s}, 1 \mathrm{H}), 8.46(\mathrm{~s}, 1 \mathrm{H}), 7.99(\mathrm{t}, J=1.9 \mathrm{~Hz}, 1 \mathrm{H})$, $7.93(\mathrm{~d}, J=8.1 \mathrm{~Hz}, 1 \mathrm{H}), 7.76(\mathrm{~d}, J=7.7 \mathrm{~Hz}, 1 \mathrm{H}), 7.67(\mathrm{~d}, J=8.1 \mathrm{~Hz}, 1 \mathrm{H}), 7.51$ (ddd, $J=8.1 \mathrm{~Hz}$, $J=6.8 \mathrm{~Hz}, J=1.3 \mathrm{~Hz}, 1 \mathrm{H}), 7.47-7.34(\mathrm{~m}, 3 \mathrm{H}), 7.2(\mathrm{~d}, J=8.1 \mathrm{~Hz}, 1 \mathrm{H}) ;{ }^{13} \mathrm{C}-\mathrm{NMR}$ (DMSO- $\left.d_{6}\right)$, $\delta: 165.77,153.42,139.95,135.73,133.06,130.45,130.35,128.61,128.09,126.81,125.73,123.71$, 123.60, 122.03, 119.80, 118.73, 110.52; HR-MS: for $\mathrm{C}_{17} \mathrm{H}_{13} \mathrm{ClNO}_{2}[\mathrm{M}+\mathrm{H}]^{+}$calculated $298.0629 \mathrm{~m} / z$, found $298.0637 \mathrm{~m} / \mathrm{z}$.

N-(4-Chlorophenyl)-3-hydroxynaphthalene-2-carboxamide (5c). Yield 71\%; Mp. 263-264 ${ }^{\circ} \mathrm{C}$ (Mp. $260{ }^{\circ} \mathrm{C}$ [34]); HPLC purity 99.35\%; IR (Zn/Se ATR, $\left.\mathrm{cm}^{-1}\right): 3283 \mathrm{w}, 3052 \mathrm{w}, 1612 \mathrm{~s}, 1549 \mathrm{~m}, 1488 \mathrm{~m}$, $1400 \mathrm{~m}, 1359 \mathrm{w}, 1334 \mathrm{w}, 1252 \mathrm{w}, 1209 \mathrm{~m}, 1170 \mathrm{~m}, 1116 \mathrm{w}, 1068 \mathrm{w}, 1012 \mathrm{~m}, 749 \mathrm{~s}, 711 \mathrm{~m}, 680 \mathrm{~m} ;{ }^{1} \mathrm{H}-\mathrm{NMR}$ $\left(\mathrm{DMSO}_{-}\right.$) $, \delta: 11.24(\mathrm{~s}, 1 \mathrm{H}), 10.68(\mathrm{~s}, 1 \mathrm{H}), 8.47(\mathrm{~s}, 1 \mathrm{H}), 7.93(\mathrm{~d}, J=7.7 \mathrm{~Hz}, 1 \mathrm{H}), 7.8(\mathrm{t}, J=9.6 \mathrm{~Hz}$, 2H), 7.54-7.46 (m, 2H), 7.42-7.32 (m, 4H); ${ }^{13} \mathrm{C}-\mathrm{NMR}$ (DMSO- $\left.d_{6}\right), \delta: 165.69,153.56,137.42,135.74$, 130.45, 130.40, 128.61, 128.08, 127.61, 126.81, 125.73, 123.70, 121.97, 121.83, 110.53; HR-MS: for $\mathrm{C}_{17} \mathrm{H}_{13} \mathrm{ClNO}_{2}[\mathrm{M}+\mathrm{H}]^{+}$calculated $298.0629 \mathrm{~m} / \mathrm{z}$, found $298.0636 \mathrm{~m} / \mathrm{z}$. 
N-(2-Bromophenyl)-3-hydroxynaphthalene-2-carboxamide (6a). Yield 61\%; Mp. $215-216{ }^{\circ} \mathrm{C}$; HPLC purity $97.75 \%$; IR (Zn/Se ATR, $\left.\mathrm{cm}^{-1}\right): 3158 \mathrm{w}, 1623 \mathrm{~s}, 1582 \mathrm{~s}, 1537 \mathrm{~s}, 1446 \mathrm{w}, 1434 \mathrm{~m}, 1388 \mathrm{w}, 1343 \mathrm{~m}$, 1312w, 1291w, 1193w, 1071w, 1047w, 1024m, 916m, 873m, 845m, 750s, 698m; ${ }^{1} \mathrm{H}-\mathrm{NMR}$ (DMSO- $d_{6}$ ), $\delta$ : $11.88(\mathrm{~s}, 1 \mathrm{H}), 11.00(\mathrm{~s}, 1 \mathrm{H}), 8.72(\mathrm{~s}, 1 \mathrm{H}), 8.42(\mathrm{dd}, J=8.1 \mathrm{~Hz}, J=1.3 \mathrm{~Hz}, 1 \mathrm{H}), 7.98(\mathrm{~d}, J=8.1 \mathrm{~Hz}$ 1H), 7.80-7.70 (m, 2H), 7.57-7.50 (m, 2H), 7.45-7.34 (m, 2H), 7.13 (dt $J=7.7 \mathrm{~Hz}, J=1.7 \mathrm{~Hz}, 1 \mathrm{H})$; ${ }^{13} \mathrm{C}-\mathrm{NMR}\left(\mathrm{DMSO}-d_{6}\right.$ ), $\delta: 163.67,152.77,136.53,136.02,132.59,132.54,128.99,128.45,128.28$, 127.10, 125.82, 125.64, 123.88, 123.50, 120.47, 114.35, 110.76; HR-MS: for $\mathrm{C}_{17} \mathrm{H}_{13} \mathrm{BrNO}_{2}[\mathrm{M}+\mathrm{H}]^{+}$ calculated $342.0124 \mathrm{~m} / \mathrm{z}$, found $342.0133 \mathrm{~m} / \mathrm{z}$.

N-(3-Bromophenyl)-3-hydroxynaphthalene-2-carboxamide (6b). Yield 73\%; Mp. 251-252 ${ }^{\circ} \mathrm{C}$; HPLC purity $98.67 \%$; IR (Zn/Se ATR, $\left.\mathrm{cm}^{-1}\right): 3295 \mathrm{w}, 3075 \mathrm{w}, 1622 \mathrm{~m}, 1583 \mathrm{~m}, 1553 \mathrm{w}, 1479 \mathrm{~m}, 1403 \mathrm{w}, 1239 \mathrm{w}$,

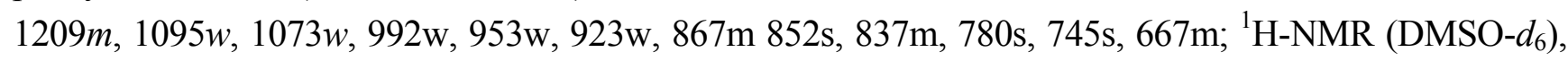
$\delta: 11.16(\mathrm{~s}, 1 \mathrm{H}), 10.00(\mathrm{~s}, 1 \mathrm{H}), 8.46(\mathrm{~s}, 1 \mathrm{H}), 8.13(\mathrm{~s}, 1 \mathrm{H}), 7.92(\mathrm{~d}, J=7.69 \mathrm{~Hz}, 1 \mathrm{H}), 7.78-7.68(\mathrm{~m}, 2 \mathrm{H})$, 7.51 (ddd, $J=8.1 \mathrm{~Hz}, J=6.8 \mathrm{~Hz}, J=1.3 \mathrm{~Hz}, 1 \mathrm{H}), 7.40-7.33(\mathrm{~m}, 4 \mathrm{H}) ;{ }^{13} \mathrm{C}-\mathrm{NMR}$ (DMSO- $\left.d_{6}\right), \delta$ : $165.79,153.44,140.08,135.74,130.66,130.43,128.62,128.09,126.80,126.51,125.74,123.72$, 122.66, 122.00, 121.48, 119.14, 110.52; HR-MS: for $\mathrm{C}_{17} \mathrm{H}_{13} \mathrm{BrNO}_{2}[\mathrm{M}+\mathrm{H}]^{+}$calculated $342.0124 \mathrm{~m} / z$, found $342.0130 \mathrm{~m} / z$.

N-(4-Bromophenyl)-3-hydroxynaphthalene-2-carboxamide (6c). Yield 69\%; Mp. 253-254 ${ }^{\circ} \mathrm{C}$ (Mp. 248-249 ${ }^{\circ} \mathrm{C}$ [35]); HPLC purity 99.02\%; IR (Zn/Se ATR, $\left.\mathrm{cm}^{-1}\right): 3288 \mathrm{w}, 3052 \mathrm{w}, 1605 \mathrm{~s}, 1544 \mathrm{~m}, 1486 \mathrm{~s}$, $1447 \mathrm{w}, 1394 \mathrm{~m}, 1360 \mathrm{w}, 1251 \mathrm{w}, 1209 \mathrm{~m}, 1169 \mathrm{w}, 1075 \mathrm{~m}, 1010 \mathrm{~m}, 955 \mathrm{w}, 915 \mathrm{w}, 871 \mathrm{~m}, 828 \mathrm{~s}, 810 \mathrm{~s}, 785 \mathrm{~m}$, 749s, 712m; ${ }^{1} \mathrm{H}-\mathrm{NMR}$ (DMSO-d $)_{6}$, $\delta: 11.22(\mathrm{~s}, 1 \mathrm{H}), 10.67(\mathrm{~s}, 1 \mathrm{H}), 8.46(\mathrm{~s}, 1 \mathrm{H}) 7.92$ (d, J= $7.7 \mathrm{~Hz}$, $1 \mathrm{H}), 7.76(\mathrm{~d}, J=8.6 \mathrm{~Hz}, 3 \mathrm{H}), 7.59-7.46(\mathrm{~m}, 3 \mathrm{H}), 7.39-7.32(\mathrm{~m}, 2 \mathrm{H}) ;{ }^{13} \mathrm{C}-\mathrm{NMR}$ (DMSO- $\left.d_{6}\right), \delta: 165.66$, 153.51, 137.83, 135.72, 131.52, 130.39, 128.60, 128.06, 126.80, 125.70, 123.69, 122.30, 121.87, 115.63, 110.52; HR-MS: for $\mathrm{C}_{17} \mathrm{H}_{13} \mathrm{BrNO}_{2}[\mathrm{M}+\mathrm{H}]^{+}$calculated $342.0124 \mathrm{~m} / \mathrm{z}$, found $342.0132 \mathrm{~m} / \mathrm{z}$.

3-Hydroxy-N-(2-trifluoromethylphenyl)naphthalene-2-carboxamide (7a). Yield 49\%; Mp. 209-210 ${ }^{\circ} \mathrm{C}$; HPLC purity 99.66\%; IR (Zn/Se ATR, $\mathrm{cm}^{-1}$ ): 3274w, 1660w, 1626w, 1597w, 1515m, 1466s, 1352w, $1278 \mathrm{~s}, 1217 \mathrm{w}, 1198 w, 1146 \mathrm{~m}, 1071 \mathrm{w}, 956 \mathrm{~m}, 874 m, 833 m, 788 m, 748 w, 722 \mathrm{~m} ;{ }^{1} \mathrm{H}-\mathrm{NMR}$ (DMSO- $d_{6}$ ), $\delta: 11.67(\mathrm{~s}, 1 \mathrm{H}), 10.43(\mathrm{~s}, 1 \mathrm{H}), 8.72(\mathrm{~s}, 1 \mathrm{H}), 7.99(\mathrm{~d}, J=8.1 \mathrm{~Hz}, 1 \mathrm{H}), 7.86(\mathrm{~d}, J=7.8 \mathrm{~Hz}, 1 \mathrm{H})$, $7.83-7.77(\mathrm{~m}, 2 \mathrm{H}), 7.70-7.66(\mathrm{~m}, 1 \mathrm{H}), 7.62-7.57(\mathrm{~m}, 1 \mathrm{H}), 7.53$ (ddd, $J=7.0 \mathrm{~Hz}, J=5.5 \mathrm{~Hz}$, $J=1.1 \mathrm{~Hz}, 1 \mathrm{H}), 7.40(\mathrm{~s}, 1 \mathrm{H}), 7.36(\mathrm{ddd}, J=8.4 \mathrm{~Hz}, J=7.0 \mathrm{~Hz}, J=1.1 \mathrm{~Hz}) ;{ }^{13} \mathrm{C}-\mathrm{NMR}$ (DMSO- $\left.d_{6}\right), \delta$ : $167.12,153.35,135.78,135.47$ (q, $J=3.9 \mathrm{~Hz}), 133.15,131.16,130.42,128.63,128.12,126.86,126.45$ $(\mathrm{q}, J=4.6 \mathrm{~Hz}), 126.16(\mathrm{q}, J=29.6 \mathrm{~Hz}), 125.75,123.75,123.70,(\mathrm{q}, \mathrm{J}=276.2 \mathrm{~Hz}), 122.11,120.19$, 110.55; HR-MS: for $\mathrm{C}_{18} \mathrm{H}_{13} \mathrm{NO}_{2} \mathrm{~F}_{3}[\mathrm{M}+\mathrm{H}]^{+}$calculated $332.0893 \mathrm{~m} / \mathrm{z}$, found $332.0898 \mathrm{~m} / z$.

3-Hydroxy-N-(3-trifluoromethylphenyl)naphthalene-2-carboxamide (7b). Yield 64\%; Mp. 239-240 ${ }^{\circ} \mathrm{C}$; HPLC purity 98.81\%; IR (Zn/Se ATR, $\mathrm{cm}^{-1}$ ): 3296w, 3108w, 1626s, 1575m, 1494m, 1428w, 1399w, $1361 \mathrm{w}, 1327 \mathrm{~s}, 1207 \mathrm{~m}, 1178 \mathrm{~s}, 1148 \mathrm{~m}, 1118 \mathrm{~s}, 1100 \mathrm{~m}, 1076 \mathrm{~m}, 925 \mathrm{w}, 893 \mathrm{~m}, 867 \mathrm{~s}, 840 \mathrm{~m}, 803 \mathrm{~s}, 771 \mathrm{~m}$, 750s, 696s, 680m; ${ }^{1} \mathrm{H}-\mathrm{NMR}$ (DMSO-d $), \delta: 11.16(\mathrm{~s}, 1 \mathrm{H}), 10.83(\mathrm{~s}, 1 \mathrm{H}), 8.45(\mathrm{~s}, 1 \mathrm{H}), 8.29(\mathrm{~s}, 1 \mathrm{H})$, $7.96(\mathrm{t}, J=8.1 \mathrm{~Hz}, 2 \mathrm{H}), 7.97(\mathrm{~d}, J=8.1 \mathrm{~Hz}, 1 \mathrm{H}), 7.62(\mathrm{t}, J=7.9 \mathrm{~Hz}, 1 \mathrm{H}), 7.55-7.47(\mathrm{~m}, 2 \mathrm{H})$, 7.40-7.32 (m, 2H); ${ }^{13} \mathrm{C}-\mathrm{NMR}$ (DMSO-d $), \delta: 166.06,153.46,139.32,135.79,130.45,129.93,129.51$ (q, $J=31.3 \mathrm{~Hz}), 128.63,128.13,126.84,125.76,124.11$ (q, $J=277.7 \mathrm{~Hz}), 123.94,123.76,122.09$, 
120.21 (q, $J=3.8 \mathrm{~Hz}$ ), 116.47 (q, $J=3.8 \mathrm{~Hz}$ ), 110.54; HR-MS: for $\mathrm{C}_{18} \mathrm{H}_{13} \mathrm{NO}_{2} \mathrm{~F}_{3}[\mathrm{M}+\mathrm{H}]^{+}$calculated $332.0893 \mathrm{~m} / \mathrm{z}$, found $332.0900 \mathrm{~m} / \mathrm{z}$.

3-Hydroxy-N-(4-trifluoromethylphenyl)naphthalene-2-carboxamide (7c). Yield 58\%; Mp. 281-282 ${ }^{\circ} \mathrm{C}$; HPLC purity 99.46\%; IR (Zn/Se ATR, $\left.\mathrm{cm}^{-1}\right): 3292 \mathrm{w}, 3021 \mathrm{w}, 1623 \mathrm{~s}, 1548 \mathrm{~m}, 1450 \mathrm{~m}, 1410 \mathrm{~m}, 1324 \mathrm{~m}$, $1255 \mathrm{w}, 1212 \mathrm{~m}, 1175 \mathrm{~m}, 1112 \mathrm{~s}, 1065 \mathrm{~s}, 1016 \mathrm{~m}, 960 \mathrm{w}, 916 \mathrm{w}, 873 \mathrm{~m}, 841 \mathrm{~s}, 822 \mathrm{~m}, 791 \mathrm{w}, 752 \mathrm{~s}, 707 \mathrm{~m}$; ${ }^{1} \mathrm{H}-\mathrm{NMR}\left(\mathrm{DMSO}-d_{6}\right), \delta: 11.17(\mathrm{~s}, 1 \mathrm{H}), 10.85(\mathrm{~s}, 1 \mathrm{H}), 8.45(\mathrm{~s}, 1 \mathrm{H}), 8.03-7.91(\mathrm{~m}, 3 \mathrm{H}), 7.79-7.72(\mathrm{~m}$, $3 \mathrm{H}), 7.51(\mathrm{ddd}, J=8.1 \mathrm{~Hz}, J=6.8 \mathrm{~Hz}, J=1.3 \mathrm{~Hz}, 1 \mathrm{H}), 7.40-7.32(\mathrm{~m}, 2 \mathrm{H}) ;{ }^{13} \mathrm{C}-\mathrm{NMR}$ (DMSO- $\left.d_{6}\right), \delta$ : $165.87,153.28,142.15$ (q, $J=1.5 \mathrm{~Hz}), 135.76,130.61,128.64,128.12,126.86,125.98$ (q, $J=3.8 \mathrm{~Hz}$ ), $125.74,124.30$ (q, $J=271.2 \mathrm{~Hz}), 123.88$ (q, $J=32.0 \mathrm{~Hz}$ ), 123.74, 122.28, 120.18, 110.53; HR-MS: for $\mathrm{C}_{18} \mathrm{H}_{13} \mathrm{NO}_{2} \mathrm{~F}_{3}[\mathrm{M}+\mathrm{H}]^{+}$calculated $332.0893 \mathrm{~m} / \mathrm{z}$, found $332.0899 \mathrm{~m} / \mathrm{z}$.

3-Hydroxy-N-(2-nitrophenyl)naphthalene-2-carboxamide (8a). Yield 29\%; Mp. 174-175 ${ }^{\circ} \mathrm{C}$; HPLC purity $97.17 \%$; IR (Zn/Se ATR, $\left.\mathrm{cm}^{-1}\right): 3240 \mathrm{w}, 1627 \mathrm{~m}, 1581 \mathrm{~m}, 1557 \mathrm{w}, 1494 \mathrm{~m}, 1450 \mathrm{w}, 1434 \mathrm{w}, 1393 \mathrm{w}$, $1341 \mathrm{~m}, 1270 \mathrm{~m}, 1203 \mathrm{w}, 1147 \mathrm{~m}, 870 \mathrm{w}, 840 \mathrm{~m}, 771 \mathrm{w}, 736 \mathrm{~s}, 691 \mathrm{w} ;{ }^{1} \mathrm{H}-\mathrm{NMR}$ (DMSO-d (D) $\delta: 12.05$ (s, $1 \mathrm{H}), 11.79(\mathrm{~s}, 1 \mathrm{H}), 8.73(\mathrm{~s}, 1 \mathrm{H}), 8.60(\mathrm{dd}, J=7.2 \mathrm{~Hz}, J=1.2 \mathrm{~Hz}, 1 \mathrm{H}), 8.16(\mathrm{dd}, J=8.2 \mathrm{~Hz}, J=1.5 \mathrm{~Hz}$, $1 \mathrm{H}), 7.97(\mathrm{t}, J=8.0 \mathrm{~Hz}, 2 \mathrm{H}), 7.82-7.78(\mathrm{~m}, 1 \mathrm{H}), 7.51(\mathrm{ddd}, J=8.1 \mathrm{~Hz}, J=6.8 \mathrm{~Hz}, J=1.3 \mathrm{~Hz}, 1 \mathrm{H})$, 7.39-7.34 (m, 3H); ${ }^{13} \mathrm{C}-\mathrm{NMR}$ (DMSO- $d_{6}$ ), $\delta: 164.21,155.98,152.85,137.18,136.17,132.97,132.43$, $129.16,128.94,127.04,126.62,125.89,125.63,123.75,120.74,115.27,110,75$; HR-MS: for $\mathrm{C}_{17} \mathrm{H}_{13} \mathrm{~N}_{2} \mathrm{O}_{4}[\mathrm{M}+\mathrm{H}]^{+}$calculated $309.0870 \mathrm{~m} / \mathrm{z}$, found $309.0875 \mathrm{~m} / \mathrm{z}$.

3-Hydroxy-N-(3-nitrophenyl)naphthalene-2-carboxamide (8b). Yield 58\%; Mp. 250-251 ${ }^{\circ} \mathrm{C}$; (Mp. 242-244 ${ }^{\circ} \mathrm{C}$ [34]); HPLC purity 97.62\%; IR (Zn/Se ATR, $\left.\mathrm{cm}^{-1}\right): 3394 \mathrm{w}, 1658 \mathrm{~m}, 1586 \mathrm{~m}, 1525 \mathrm{~m}$, $1463 \mathrm{~m}, 1345 \mathrm{~s}, 1297 \mathrm{~s}, 1230 \mathrm{~m}, 1209 \mathrm{~m}, 1145 \mathrm{~m}, 1033 \mathrm{w}, 911 \mathrm{w}, 876 \mathrm{~m}, 808 \mathrm{~m}, 747 \mathrm{~m}, 738 \mathrm{~s}, 668 \mathrm{~m}$; ${ }^{1} \mathrm{H}-\mathrm{NMR}\left(\mathrm{DMSO}-d_{6}\right), \delta: 11.12(\mathrm{~s}, 1 \mathrm{H}), 10.93(\mathrm{~s}, 1 \mathrm{H}), 8.83(\mathrm{t}, J=2.14 \mathrm{~Hz}, 1 \mathrm{H}), 8.45(\mathrm{~s}, 1 \mathrm{H}), 8.11(\mathrm{dd}$, $J=8.12 \mathrm{~Hz}, J=1.28 \mathrm{~Hz}, 1 \mathrm{H}), 8.01-7.91(\mathrm{~m}, 2 \mathrm{H}), 7.77(\mathrm{~d}, J=8.1 \mathrm{~Hz}, 1 \mathrm{H}), 7.66(\mathrm{t}, J=8.1 \mathrm{~Hz}, 1 \mathrm{H})$, $7.51(\mathrm{ddd}, J=8.1 \mathrm{~Hz}, J=6.8 \mathrm{~Hz}, J=1.3 \mathrm{~Hz}, 1 \mathrm{H}), 7.40-7.32(\mathrm{~m}, 2 \mathrm{H}) ;{ }^{13} \mathrm{C}-\mathrm{NMR}$ (DMSO-d $), \delta$ : $166.08,153.30,147.95,139.72,135.76,130.48,130.08,128.61,128.12,126.80,126.24,125.76$, 123.76, 122.22, 118.32, 114.35, 110.50; HR-MS: for $\mathrm{C}_{17} \mathrm{H}_{13} \mathrm{~N}_{2} \mathrm{O}_{4}[\mathrm{M}+\mathrm{H}]^{+}$calculated $309.0870 \mathrm{~m} / z$, found $309.0876 \mathrm{~m} / \mathrm{z}$.

3-Hydroxy-N-(4-nitrophenyl)naphthalene-2-carboxamide (8c). Yield 72\%; Mp. 265-266 ${ }^{\circ} \mathrm{C}$; HPLC purity $99.03 \%$; IR (Zn/Se ATR, $\left.\mathrm{cm}^{-1}\right)$ : 3285w, 2981w, 1618s, 1599m, 1568w, 1513s, 1449w, 1407w, $1337 \mathrm{~s}, 1260 \mathrm{w}, 1210 \mathrm{~m}, 1171 \mathrm{~m}, 1147 \mathrm{w}, 1112 \mathrm{~m}, 1033 \mathrm{~m}, 916 \mathrm{w}, 851 \mathrm{~s}, 772 \mathrm{w}, 747 \mathrm{~s}, 704 \mathrm{w} ;{ }^{1} \mathrm{H}-\mathrm{NMR}$ $\left(\mathrm{DMSO}-d_{6}\right), \delta: 11.10(\mathrm{~s}, 1 \mathrm{H}), 11.03(\mathrm{~s}, 1 \mathrm{H}), 8.41(\mathrm{~s}, 1 \mathrm{H}), 8.28(\mathrm{~d}, J=9.4 \mathrm{~Hz}, 2 \mathrm{H}), 8.03(\mathrm{~d}, J=9.0 \mathrm{~Hz}$, 2H), $7.93(\mathrm{~d}, J=8.1 \mathrm{~Hz}, 1 \mathrm{H}), 7.77(\mathrm{~d}, J=8.6 \mathrm{~Hz}, 1 \mathrm{H}), 7.51$ (ddd, $J=8.1 \mathrm{~Hz}, J=6.8 \mathrm{~Hz}, J=1.3 \mathrm{~Hz}$, $1 \mathrm{H}), 7.39-7.32(\mathrm{~m}, 2 \mathrm{H}) ;{ }^{13} \mathrm{C}-\mathrm{NMR}$ (DMSO- $\left.d_{6}\right), \delta: 165.89,152.98,144.80,142.58,135.76,130.73$, $128.63,128.15,126.85,125.75,124.82,123.76,122.68,119.79,110.49$; HR-MS: for $\mathrm{C}_{17} \mathrm{H}_{13} \mathrm{~N}_{2} \mathrm{O}_{4}$ $[\mathrm{M}+\mathrm{H}]^{+}$calculated $309.0870 \mathrm{~m} / \mathrm{z}$, found $309.0875 \mathrm{~m} / \mathrm{z}$.

\subsection{Lipophilicity Determination by HPLC (Capacity Factor k/Calculated log k)}

A HPLC system Agilent 1200 equipped with DAD detector (Agilent, Santa Clara, CA, USA) was used. A chromatographic column Symmetry ${ }^{\circledR} \mathrm{C}_{18} 5 \mu \mathrm{m}, 4.6 \times 250 \mathrm{~mm}$, Part No. WAT054275, (Waters Corp., Milford, MA, USA) was used. The HPLC separation process was monitored and evaluated by 
EZChrom Elite software ver. 3.3.2 (Agilent). Isocratic elution by a mixture of $\mathrm{MeOH}$ p.a. (60\%) and $\mathrm{H}_{2} \mathrm{O}-\mathrm{HPLC}$ Mili-Q grade $(40 \%)$ as a mobile phase was used. The total flow of the column was $1.0 \mathrm{~mL} / \mathrm{min}$, injection $20 \mu \mathrm{L}$, column temperature $40{ }^{\circ} \mathrm{C}$ and sample temperature $10{ }^{\circ} \mathrm{C}$. The detection wavelength $210 \mathrm{~nm}$ was chosen. The KI methanolic solution was used for the dead time $\left(t_{D}\right)$ determination. Retention times $\left(t_{\mathrm{R}}\right)$ were measured in minutes. The capacity factors $k$ were calculated according to formula $k=\left(t_{R}-t_{D}\right) / t_{D}$, where $t_{R}$ is the retention time of the solute, whereas $t_{D}$ denotes the dead time obtained using an unretained analyte. $\log k$, calculated from the capacity factor $k$, is used as the lipophilicity index converted to $\log P$ scale. The $\log k$ values of the individual compounds are shown in Table 1.

\subsection{Study of Inhibition of Photosynthetic Electron Transport (PET) in Spinach Chloroplasts}

Chloroplasts were prepared from spinach (Spinacia oleracea L.) according to Masarovicova and Kralova [51]. The inhibition of photosynthetic electron transport (PET) in spinach chloroplasts was determined spectrophotometrically (Genesys 6, Thermo Scientific), using an artificial electron acceptor 2,6-dichlorophenol-indophenol (DCIPP) according to Kralova et al. [52], and the rate of photosynthetic electron transport was monitored as a photoreduction of DCPIP. The measurements were carried out in phosphate buffer $(0.02 \mathrm{~mol} / \mathrm{L}, \mathrm{pH} 7.2)$ containing sucrose $(0.4 \mathrm{~mol} / \mathrm{L}), \mathrm{MgCl}_{2}$ $(0.005 \mathrm{~mol} / \mathrm{L})$ and $\mathrm{NaCl}(0.015 \mathrm{~mol} / \mathrm{L})$. The chlorophyll content was $30 \mathrm{mg} / \mathrm{L}$ in these experiments and the samples were irradiated $\left(\sim 100 \mathrm{~W} / \mathrm{m}^{2}\right.$ with $10 \mathrm{~cm}$ distance) with a halogen lamp $(250 \mathrm{~W})$ using a 4 $\mathrm{cm}$ water filter to prevent warming of the samples (suspension temperature $22{ }^{\circ} \mathrm{C}$ ). The studied compounds were dissolved in DMSO due to their limited water solubility. The applied DMSO concentration (up to $4 \%$ ) did not affect the photochemical activity in spinach chloroplasts. The inhibitory efficiency of the studied compounds was expressed by $\mathrm{IC}_{50}$ values, i.e., by molar concentration of the compounds causing 50\% decrease in the oxygen evolution rate relative to the untreated control. The comparable $\mathrm{IC}_{50}$ value for a selective herbicide 3-(3,4-dichlorophenyl)-1,1-dimethylurea, DCMU (Diurone $^{\circledR}$ ) was about $1.9 \mu \mathrm{mol} / \mathrm{L}$. The results are summarized in Table 1.

\subsection{Study of Chlorophyll a Fluorescence in Spinach Chloroplasts}

The fluorescence emission spectra of chlorophyll $a(\mathrm{Chl} a)$ in spinach chloroplasts were recorded on fluorescence spectrophotometer F-2000 (Hitachi, Tokyo, Japan) using excitation wavelength $\lambda_{\mathrm{ex}}=436 \mathrm{~nm}$ for monitoring fluorescence of Chla, excitation slit $20 \mathrm{~nm}$ and emission slit $10 \mathrm{~nm}$. The samples were kept in the dark for 2 min before measuring. The phosphate buffer used for dilution of the chloroplast suspension was the same as described above. Due to low aqueous solubility the compounds were added to chloroplast suspension in DMSO solution. The DMSO concentration in all samples was the same as in the control (10\%). The chlorophyll concentration in chloroplast suspension was $10 \mathrm{mg} / \mathrm{L}$.

\subsection{In Vitro Antibacterial Susceptibility Testing}

The synthesized compounds were evaluated for in vitro antibacterial activity against representatives of multidrug-resistant bacteria, clinical isolates of methicillin-resistant Staphylococcus aureus (MRSA) 63718, SA 630 and SA 3202 that were obtained from the National Institute of Public Health, 
Prague, Czech Republic. Staphylococcus aureus ATCC 29213 was used as a reference and quality control strain. Ampicillin (Sigma-Aldrich) was used as the standard. Prior to testing, each strain was passaged onto nutrient agar (Oxoid, Hampshire, UK) with $5 \%$ of bovine blood, and bacterial inocula were prepared by suspending a small portion of bacterial colony in sterile phosphate buffered saline ( $\mathrm{pH}$ 7.2-7.3). The cell density was adjusted to 0.5 McFarland units using a densitometer (Densi-La-Meter, LIAP, Riga, Latvia). The final inoculum was made by 1:20 dilution of the suspension with the Mueller-Hinton broth (MH broth). The compounds were dissolved in DMSO (Sigma), and the final concentration of DMSO in the MH broth (Oxoid) did not exceed 2.5\% of the total solution composition. The broth dilution micro-method modified according to NCCLS guidelines $[53,54]$ in $\mathrm{MH}$ broth was used to determine the minimum inhibitory concentration (MIC). Drug-free controls, sterility controls and controls consisted of MH broth and DMSO alone were included. The determination of results was performed visually after $24 \mathrm{~h}$ of static incubation in the darkness at $37{ }^{\circ} \mathrm{C}$ in an aerobic atmosphere. The MICs were defined as the lowest concentration of the compound at which no visible bacterial growth was observed. The results are summarized in Table 1.

\subsection{In Vitro Antimycobacterial Evaluation}

The evaluation of in vitro antimycobacterial activity of the compounds was performed against Mycobacterium marinum CAMP 5644 and M. kansasii DSM 44162. The broth dilution micro-method in Middlebrook 7H9 medium (Difco, Lawrence, KS, USA) supplemented with ADC Enrichment (BBL, USA) was used to determine the minimum inhibitory concentration (MIC) as previously described [55]. The tested compounds were dissolved as described above in chapter 3.6. Isoniazid (Sigma-Aldrich) was used as reference antibacterial drug. Bacterial inocula were prepared by transferring colonies from culture to sterile water. The cell density was adjusted to $0.5 \mathrm{McFarland}$ units using a densitometer (Densi-La-Meter, LIAP). The final inoculum was made by 1:1,000 dilution of the suspension with sterile water. Drug-free controls, sterility controls and controls consisted of medium and DMSO alone were included. The determination of results was performed visually after 7 days of static incubation in the darkness at $37^{\circ} \mathrm{C}$ in an aerobic atmosphere for M. kansasii and after 21 days of static incubation in the darkness at $28^{\circ} \mathrm{C}$ in an aerobic atmosphere for M. marinum. The MICs were defined as the lowest concentration of the compound at which no visible bacterial growth was observed. The results are summarized in Table 1.

\subsection{In Vitro Cytotoxicity Assay}

Human monocytic leukemia THP-1 cells were used for in vitro toxicity assay. Cells were obtained from the European Collection of Cell Cultures (ECACC, Salisbury, UK) and routinely cultured in RPMI medium supplemented with 10\% fetal bovine serum, 2\% L-glutamine, 1\% penicillin and streptomycin at $37{ }^{\circ} \mathrm{C}$ with $5 \% \mathrm{CO}_{2}$. Cytotoxicity was determined using a WST-1 assay kit (Roche Diagnostics, Mannheim, Germany) according to the manufacturer's instructions. The tested compounds were dissolved in DMSO and added in five increasing concentrations $(0.37,1.1,3.3,10$, and $30 \mu \mathrm{mol} / \mathrm{L}$ ) to the cell suspension in the culture medium. Subsequently, the cells were incubated for $24 \mathrm{~h}$ at $37{ }^{\circ} \mathrm{C}$ with $5 \% \mathrm{CO}_{2}$. WST-1 assays conducted in triplicates were performed as previously described [49]. The median lethal dose values, $\mathrm{LD}_{50}$, were deduced through the production of a dose- 
response curve. All data were evaluated using GraphPad Prism 5.00 software (GraphPad Software, San Diego, CA, USA). The results are summarized in Table 1.

\section{Conclusions}

A series of twenty-two ring-substituted 3-hydroxynaphthalene-2-carboxanilides were prepared and characterized. The prepared compounds were tested for their ability to inhibit photosynthetic electron transport (PET) in spinach chloroplasts (Spinacia oleracea L.) and for their antibacterial and antimycobacterial activity against four Staphylococcus strains, Mycobacterium marinum and M. kansasii. 3-Hydroxy- $N$-(3-nitrophenyl)naphthalene-2-carboxamide (8b) showed relatively high PET inhibition. 3-Hydroxy- $N$-(2-methoxyphenyl)naphthalene-2-carboxamide (2a) showed the high biological activity against $S$. aureus as well as methicillin-resistant strains. $N$-(2-Fluorophenyl)-3hydroxynaphthalene-2-carboxamide (4a) and $N$-(3-fluorophenyl)-3-hydroxynaphthalene-2-carboxamide (4b) expressed high activity against $M$. marinum. 3-Hydroxy- $N$-(4-nitrophenyl)naphthalene-2carboxamide (8c) showed high activity against M. kansasii. All the above-mentioned compounds exhibited activity comparable with or higher than the standards ampicillin or isoniazid. Lipophilicity and electronic properties of anilide substituents influenced the biological activities of compounds in all biological assays. It can be stated that the dependences of activities on lipophilicity and on electronic properties show bilinear trends. The most effective compounds $\mathbf{2 a}, \mathbf{4 a}, \mathbf{7 a}, \mathbf{8 b}$ and $\mathbf{8 c}$ were tested for their in vitro cytotoxicity against THP-1 cells. It can be concluded that the discussed anilides 2a and 4a can be considered as promising agents for subsequent design of novel antibacterial and antimycobacterial agents.

\section{Acknowledgements}

This study was supported by the IGA VFU Brno 96/2012/FaF and 65/2012/FVL, the Slovak Grant Agency VEGA, Grant No. 1/0612/11, by the Project APVV-0061-11, by Sanofi-Aventis Pharma Slovakia, by the Project CzechGlobe (Centre for Global Climate Change Impacts Studies), Reg. No. CZ.1.05/1.1.00/02.0073, and by the project CEITEC (Central European Institute of Technology), Reg. No. CZ.1.05/1.1.00/02.0068 from the European Regional Development Fund.

\section{Conflict of Interest}

The authors declare no conflict of interest.

\section{References}

1. Baquero, F.; Coque, T.M.; de la Cruz, F. Ecology and evolution as targets: the need for novel eco-evo drugs and strategies to fight antibiotic resistance. Antimicrob. Agents Chemother. 2011, $55,3649-3660$.

2. Acharya, N.; Varshney, U. Biochemical properties of single-stranded DNA-binding protein from Mycobacterium smegmatis, a fast-growing Mycobacterium and its physical and functional interaction with uracil DNA glycosylases. J. Mol. Biol. 2002, 318, 1251-1264. 
3. Broussard, G.W.; Ennis, D.G. Mycobacterium marinum produces long-term chronic infections in medaka: A new animal model for studying human tuberculosis. Comp. Biochem. Phys. C 2007, 145, 45-54.

4. Matveychuk, A.; Fuks, L.; Priess, R.; Hahim, I.; Shitrit D. Clinical and radiological features of Mycobacterium kansasii and other NTM infections. Resp. Med. 2012, 106, 1472-1477.

5. Laughon, E.L. New tuberculosis drugs in development. Curr. Top. Med. Chem. 2007, 7, 463-473.

6. Levy, S.B. Antibiotic resistance-the problem intensifies. Adv. Drug. Delivery Rev. 2005, 57, 1446-1450.

7. Kallen, A.J.; Mu, Y.; Bulens, S.; Reingold, A.; Petit, S.; Gershman, K.; Ray, S.M.; Harrison, L.H.; Lynfield, R.; Dumyati, G.; et al. Health care-associated invasive MRSA infections, 20052008. JAMA 2010, 304, 641-647.

8. Liu, C.; Bayer, A.; Cosgrove, S.E.; Daum, R.S.; Fridkin, S.K.; Gorwitz, R.J.; Kaplan, S.L.; Karchmer, A.W.; Levine, D.P.; Murray, B.E.; et al. Clinical practice guidelines by the Infectious Diseases Society of America for the treatment of methicillin-resistant Staphylococcus aureus infections in adults and children. Clin. Infect. Dis. 2011, 52, 285-292.

9. Shaner, D.L. Herbicide safety relative to common targets in plants and mammals. Pest. Manag. Sci. 2004, 60, 17-24.

10. Delaney, J.; Clarke, E.; Hughes, D.; Rice, M. Modern agrochemical research: A missed opportunity for drug discovery? Drug Discov. Today 2006, 11, 839-845.

11. Duke, S.O. Herbicide and pharmaceutical relationships. Weed Sci. 2010, 58, 334-339.

12. Kralova, K.; Sersen, F.; Cizmarik, J. Inhibitory effect of piperidinoethylesters of alkoxyphenylcarbamic acids on photosynthesis. Gen. Physiol. Biophys. 1992, 11, 261-267.

13. Kralova, K.; Bujdakova, H.; Kuchta, T.; Loos, D. Correlation between biological activity and the structure of 6-amino-2-R-thiobenzothiazoles. Anti-yeast activity and inhibition of photochemical activity of chloroplasts. Pharmazie 1994, 49, 460-461.

14. Kralova, K.; Kallova, J.; Loos, D.; Devinsky, F. Correlation between biological activity and the structure of $N, N^{\prime}$-bis(alkyldimethyl)-1,6-hexanediammonium dibromides. Antibacterial activity and inhibition of photochemical activity of chloroplasts. Pharmazie 1994, 49, 857-858.

15. Kralova, K.; Bujdakova, H.; Cizmarik, J. Antifungal and antialgal activity of piperidinopropyl esters of alkoxy substituted phenylcarbamic acids. Pharmazie 1995, 50, 440-441.

16. Musiol, R.; Tabak, D.; Niedbala, H.; Podeszwa, B.; Jampilek, J.; Kralova, K.; Dohnal, J.; Finster, J.; Mencel, A.; Polanski, J. Investigating biological activity spectrum for novel quinoline analogues 2: Hydroxyquinolinecarboxamides with photosynthesis inhibiting activity. Bioorg. Med. Chem. 2008, 16, 4490-4499.

17. Imramovsky, A.; Vinsova, J.; Monreal-Ferriz, J.; Buchta, V.; Jampilek, J. Salicylanilide esters of $\mathrm{N}$-protected amino acids as novel antimicrobial agents. Bioorg. Med. Chem. Lett. 2009, 19, $348-351$.

18. Otevrel, J.; Mandelova, Z.; Pesko, M.; Guo, J.; Kralova, K.; Sersen, F.; Vejsova, M.; Kalinowski, D.; Kovacevic, Z.; Coffey, A.; et al. Investigating the spectrum of biological activity of ring-substituted salicylanilides and carbamoylphenylcarbamates. Molecules 2010, 15, 8122-8142. 
19. Imramovsky, A.; Pesko, M.; Kralova, K.; Vejsova, M.; Stolarikova, J.; Vinsova, J.; Jampilek, J. Investigating spectrum of biological activity of 4- and 5-chloro-2-hydroxy- $N$-[2-(arylamino)-1alkyl-2-oxoethyl]benzamides. Molecules 2011, 16, 2414-2430.

20. Gonec, T.; Bobal, P.; Sujan, J.; Pesko, M.; Guo, J.; Kralova, K.; Pavlacka, L.; Vesely, L.; Kreckova, E.; Kos, J.; et al. Investigating the spectrum of biological activity of substituted quinoline-2-carboxamides and their isosteres. Molecules 2012, 17, 613-644.

21. Draber, W.; Tietjen, K.; Kluth, J.F.; Trebst, A. Herbicides in photosynthesis research. Angew. Chem. 1991, 3, 1621-1633.

22. Tischer, W.; Strotmann, H. Relationship between inhibitor binding by chloroplasts and inhibition of photosynthetic electron-transport. Biochim. Biophys. Acta 1977, 460, 113-125.

23. Trebst, A.; Draber, W. Structure activity correlations of recent herbicides in photosynthetic reactions. In Advances in Pesticide Science; Greissbuehler, H., Ed.; Pergamon Press: Oxford, UK, 1979; pp. 223-234.

24. Bowyer, J.R.; Camilleri, P.; Vermaas, W.F.J. Photosystem II and its interaction with herbicides. In Herbicides, Topics in Photosynthesis; Baker, N.R., Percival, M.P., Eds.; Elsevier: Amsterdam, The Netherlands, 1991; Volume 10, pp. 27-85.

25. Koreyoshi, S.; Masato, M.; Tetsuji, I. (Yoshitomi Pharmaceutical Industries) Hydroxynaphthoic acid anilides, microbicides and slimicides. Japan. Kokai JP 52076 430, 27 June 1977.

26. Macielag, M.J.; Demers, J.P.; Fraga-Spano, S.A.; Hlasta, J.D.; Johnson, G.S.; Kanojia, M.R.; Russell, K.R.; Sui, Z.; Weidner-Wells, A.M.; Werblood, H.; et al. Substituted salicylanilides as inhibitors of two-component regulatory systems in bacteria. J. Med. Chem. 1998, 41, 2939-2945.

27. Kauppi, A.M.; Nordfelth, R.; Uvell, H.; Wolf-Watz, H.; Elofsson, M. Targeting bacterial virulence: Inhibitors of type III secretion in Yersinia. Chem. Biol. 2003, 10, 241-249.

28. Vinsova, J.; Imramovsky, A.; Buchta, V.; Ceckova, M.; Dolezal, M.; Staud, F.; Jampilek, J.; Kaustova, J. Salicylanilide acetates: Synthesis and antibacterial evaluation. Molecules 2007, 12, $1-12$.

29. Imramovsky, A.; Vinsova, J.; Monreal-Ferriz, J.; Dolezal, R.; Jampilek, J.; Kaustova, J.; Kunc, F. New antituberculotics originated from salicylanilides with promising in vitro activity against atypical mycobacterial strains. Bioorg. Med. Chem. 2009, 17, 3572-3579.

30. Imramovsky, A.; Pesko, M.; Monreal-Ferriz, J.; Kralova, K.; Vinsova, J.; Jampilek, J. Photosynthesis-Inhibiting efficiency of 4-chloro-2-(chlorophenylcarbamoyl)phenyl alkylcarbamates. Bioorg. Med. Chem. Lett. 2011, 21, 4564-4567.

31. Kratky, M.; Vinsova, J. Salicylanilide ester prodrugs as potential antimicrobial agents - a review. Curr. Pharm. Des. 2011, 17, 3494-3505.

32. Kratky, M.; Vinsova, J. Buchta, V. In vitro antibacterial and antifungal activity of salicylanilide benzoates. Sci. World J. 2012, 2012, 290628.

33. Kratky, M.; Vinsova, J.; Novotna, E.; Mandikova, J.; Wsol, V.; Trejtnar, F.; Ulmann, V.; Stolarikova, J.; Fernandes, S.; Bhat, S.; et al. Salicylanilide derivatives block Mycobacterium tuberculosis through inhibition of isocitrate lyase and methionine aminopeptidase. Tuberculosis 2012, 92, 434-439.

34. Hartrodt, V.W.; Woohsmann, H. Ein Beitrag zur Darstellun von Alkalisalzen saurer Schwefelsäureester verschiedener Naphthol AS-Verbindungen. J. Prakt. Chem. 1965, 27, 99-107. 
35. Tripathy, H.; Pradhan, D.G.; Dash, B.C.; Mahapatra, G.N. Synthesis of some new halogenated $\mathrm{N}$-thiazolyl substituted hydroxy acid amides and their use as possible fungicides. Agric. Biol. Chem. 1973, 6, 1375-1383.

36. Hitch, F.E.; Dahlen, A.M.; Friedrich, M.E. (E.I. du Pont de Nemours \& Company). Fluorinated arylamides. US 1982661, 4 December 1934.

37. Liechty, C.H.; Sequin, U.; Bold, G.; Furet, P.; Meyer, T.; Traxler, P. Salicylanilides as inhibitors of the protein tyrosine kinase epidermal growth factor receptor. Eur. J. Med. Chem. 2004, 39, $11-26$.

38. Izawa, S. Acceptors and donors for chloroplast electron transport. In Methods in Enzymology; Colowick, P., Kaplan, N.O., Eds.; Academic Press: London, UK, 1980; Volume 69, Part C, pp. 413-434.

39. Kralova, K.; Sersen, F.; Pesko, M.; Klimesova, V.; Waisser, K. Photosynthesis-inhibiting effects of 2-benzylsulphanylbenzimidazoles in spinach chloroplasts. Chem. Pap. 2012, 66, 795-799.

40. Kralova, K.; Sersen, F.; Sidoova, E. Effect of 2-alkylthio-6-aminobenzothiazoles and their 6- $N$ substituted derivatives on photosynthesis inhibition in spinach chloroplasts. Gen. Phys. Biophys. 1993, 12, 421-427.

41. Kralova, K.; Sersen, F.; Miletin, M.; Hartl, J. Inhibition of photosynthetic electron transport by some anilides of 2-alkylpyridine-4-carboxylic acids in spinach chloroplasts. Chem. Pap. 1998, 52, $52-55$.

42. Kralova, K.; Sersen, F.; Pesko, M.; Waisser, K.; Kubicova, L. 5-Bromo- and 3,5-dibromo-2hydroxy- $N$-phenylbenzamides-Inhibitors of photosynthesis. Chem. Pap. 2013, 67, in press

43. Kralova, K.; Sersen, F.; Klimesova, V.; Waisser, K. 2-Alkylsulphanyl-4-pyridinecarbothioamides-Inhibitors of oxygen evolution in freshwater alga Chlorella vulgaris. Chem. Pap. 2011, 65, 909-912.

44. Atal, N.; Saradhi, P.P.; Mohanty, P. Inhibition of the chloroplast photochemical reactions by treatment of wheat seedlings with low concentrations of cadmium: Analysis of electron transport activities and changes in fluorescence yields. Plant Cell Physiol. 1995, 32, 943-951.

45. Sersen, F.; Kralova, K.; Bumbalova A. Action of mercury on the photosynthetic apparatus of spinach chloroplasts. Photosynthetica 1998, 35, 551-559.

46. Apostolova, E.L.; Ivanov, A.G. Influence of Triton X-100on the structure and functions of pea thylakoid membranes. J. Plant Physiol. 1995, 145, 239-244.

47. Kralova, K.; Sersen, F.; Kubicova, L.; Waisser, K. Inhibitory effects of substituted benzanilides on photosynthetic electron transport in spinach chloroplasts. Chem. Pap. 1999, 53, 328-331.

48. Kubicova, L.; Kralova, K.; Sersen, F.; Gregor, J.; Waisser, K. Effects of substituted salicylanilides on the photosynthetic apparatus of spinach chloroplasts. Folia Pharm. Univ. Carol. 2000, 25, 89-96.

49. Kollar, P.; Zavalova, V.; Barta, T.; Smejkal, K.; Hampl, A. Geranylated flavanone tomentodiplacone B inhibits proliferation of human monocytic leukaemia (THP-1) cells. Br. J. Pharmacol. 2011, 162, 1534-1541.

50. Fajkusova, D.; Pesko, M.; Keltosova, S.; Guo, J.; Oktabec, Z.; Vejsova, M.; Kollar, P.; Coffey, A.; Csollei, J.; Kralova, K.; Jampilek, J.: Anti-infective and herbicidal activity of $\mathrm{N}$-substituted 2-aminobenzothiazoles. Bioorg. Med. Chem. 2012, 20, 7059-7068. 
51. Masarovicova, E.; Kralova, K. Approaches to Measuring Plant Photosynthesis Activity. In Handbook of Photosynthesis, 2nd ed.; Pessarakli, M., Ed.; Taylor \& Francis Group: Boca Raton, FL, USA, 2005; pp. 617-656.

52. Kralova, K.; Sersen, F.; Sidoova, E. Photosynthesis inhibition produced by 2-alkylthio-6-Rbenzothiazoles. Chem. Pap. 1992, 46, 348-350.

53. National Committee for Clinical Laboratory Standards. Methods for Dilution Antimicrobial Susceptibility Tests for Bacteria that Grow Aerobically, 5th Edition; Approved Standard M7-A5. NCCLS: Wayne, PA, USA, 2000.

54. National Committee for Clinical Laboratory Standards. Performance Standards for Antimicrobial Susceptibility Testing; 12th Informational Supplement M100-S12. NCCLS: Wayne, PA, USA, 2002.

55. Schwalbe, R.; Steele-Moore, L.; Goodwin, A.C. Antimicrobial Susceptibility Testing Protocols. CRC Press: Boca Raton, FL, USA, 2007.

Sample Availability: Samples of the compounds are available from the authors.

(C) 2013 by the authors; licensee MDPI, Basel, Switzerland. This article is an open access article distributed under the terms and conditions of the Creative Commons Attribution license (http://creativecommons.org/licenses/by/3.0/). 